\title{
Multifunctional Cationic PeptoStars as siRNA Carrier: Influence of Architecture and Histidine Modification on Knockdown Potential
}

\author{
Regina Holm, David Schwiertz, Benjamin Weber, Jennifer Schultze, Jasmin Kuhn, \\ Kaloian Koynov, Ulrich Lächelt, and Matthias Barz* \\ Dedicated to Prof. Helmut Ringsdorf on the occasion of his 90th birthday
}

RNA interference provides enormous potential for the treatment of several diseases, including cancer. Nevertheless, successful therapies based on siRNA require overcoming various challenges, such as poor pharmacokinetic characteristics of the small RNA molecule and inefficient cytosolic accumulation. In this respect, the development of functional siRNA carrier systems is a major task in biomedical research. To provide such a desired system, the synthesis of 3-arm and 6-arm PeptoStars is aimed for. The different branched polypept(o)idic architectures share a stealth-like polysarcosine corona for efficient shielding and a multifunctional polylysine core, which can be independently varied in size and functionality for siRNA complexation-, transport and intra cellular release. The special feature of star-like polypept(o)ides is in their uniform small size $(<20 \mathrm{~nm})$ and a core-shell structure, which implies a high stability and stealth-like properties and thus, they may combine long circulation times and a deep penetration of cancerous tissue. Initial toxicity and complement studies demonstrate well tolerated cationic PeptoStars with high complexation capability toward siRNA (N/P ratio up to 3:1), which can lead to potent RNAi for optimized systems. Here, the synthetic development of 3-arm and 6-arm polypept(o)idic star polymers, their modification with endosomolytic moieties, and first in vitro insights on RNA interference are reported on.

\section{Introduction}

Therapies based on RNA interference (RNAi) as highly specific approach for gene silencing offer a tremendous potential for the treatment of various diseases caused by pathogenic genes and their overexpression, for example, cancer. ${ }^{[-4]}$ Small interfering RNA (siRNA) enables a sequence-specific suppression of the gene expression via mRNA degradation pathways and thus, preventing protein translation. ${ }^{[5]}$ Especially in the treatment of cancer, suppressing genes seems to be a powerful tool and a promising option for current therapeutic strategies. Processes of angiogenesis, proliferation, cell cycles, and oncoprotein synthesis are counted among target gene candidates and have been tested in early-phase clinical trials for RNAi-based cancer therapy. ${ }^{[6,7]}$ However, the small negatively charged siRNA rapidly cleared by the kidneys or degraded by nucleases shows inefficient cellular internalization and cytosolic translocation. ${ }^{[8,9]}$ Consequently, this therapeutic agent requires effective and suitable carriers to reach the target site and overcome these hurdles to unleash its enormous therapeutic potential. In this regard, a broad range of nonviral gene delivery systems ${ }^{[10,11]}$ has been developed over the past decades, including lipid-based ${ }^{[12,13]}$ or polymeric systems, ${ }^{[14-16]}$ but efficient delivery of siRNA in vivo to cancerous tissue still remains challenging, because it requires long circulation times for passive accumulation together with efficient cellular uptake into target cells. These critical issues of siRNA delivery need to be considered in the development of effective siRNA delivery systems for cancer therapy.

In general, cationic polymers, such as polyethylenimine, ${ }^{[17]}$ are preferably used to complex negatively charged nucleic acids via electrostatic interactions and as result they form so-called polyplexes. ${ }^{[18,19]}$ Nevertheless, due to the small dimension of siRNA molecules, such a polyplex is not efficiently stabilized. The introduction of cross-linkers is herein imperative to create carrier systems with increased extracellular stability. ${ }^{[20]}$

DOI: 10.1002/mabi.201900152 
Furthermore, the formed polyplexes often induce high dispersity and tend to generate large aggregates. Uniform small sizes and homogeneity of carrier systems are of significant importance for the application in cancer treatment to achieve excess to cancer cells. ${ }^{[21]}$ The focus lies on the protection of siRNA from enzymatic degradation and renal clearance, simultaneously providing a deep tumor penetration by efficient diffusion of the carriers across the extracellular matrix (ECM) with dense fibrotic microenvironments. ${ }^{[22,23]}$ Many studies suggested that the size of delivery systems correlates with their systemic and intratumoral distribution and that a size range of $10-30 \mathrm{~nm}$ is suitable for, on the one hand avoiding renal clearance and on the other hand, benefiting from the EPR effect and deep tissue penetration. ${ }^{[24-27]}$ Moreover, a distinct disadvantage of cationic polymers is the interaction of the cationic complex with negatively charged serum proteins and various blood components resulting in the activation of the innate immune system, high cytotoxicity and thus, limiting a systemic application. Ideally the carrier should combine long blood circulation (half-life $\geq 2 \mathrm{~h}$ ), show target cell uptake, and efficient endosomal release. ${ }^{[28]}$ All these hurdles emphasize the urgent requirement of carrier systems possessing multifunctionalities to address those issues by conquering multiple barriers all the way to its site of action.

Moreover, the current research on novel polymeric carrier systems has indicated that branched polymers are more efficient at nucleic acid delivery than equivalent linear polymers. ${ }^{[29-32]}$ Therefore, the already introduced PeptoStars might be a promising alternative for siRNA delivery. ${ }^{[3]}$ PeptoStars consist of a polypeptidic core shielded by a hydrophilic polysarcosine corona and can be thus considered as unimolecular micelles. The synthesis of amphiphilic polypept(o)idic arms is accomplished by controlled living ring opening polymerization (ROP) of $\alpha$-amino acid $N$-carboxyanhydrides (NCAs) and corresponding $\mathrm{N}$-substituted glycine $\mathrm{N}$-carboxyanhydride (NNCA) induced by multifunctional initiator. ${ }^{[34]}$ The core-first approach facilitates the variation of arm lengths and the number of arms and therefore, independent adjustment of the functional core and the water soluble corona is feasible. In addition, particle size can be precisely controlled in the range of $10-20 \mathrm{~nm}$ by adjusting the degree of polymerization. ${ }^{33]}$ Efficient complexation of nucleic acids, such as pDNA, mRNA, and siRNA, has been already demonstrated for cationic polypeptidic cores based on polylysine. ${ }^{[35,36]}$ Furthermore, chemical modifications of the polylysine core enable the enhancement of the endosomal escape and thus foster cytosolic delivery. This can be realized by the incorporation of endosomolytic moieties like imidazoles. ${ }^{[37]}$ The hydrophilic and nonionic polypeptoid, polysarcosine, serves as hydrophilic corona material and assures stealth-like properties by shielding the cationic core. ${ }^{[38]}$ This shielding is essential to limit interactions with blood components and prevent the formation of aggregates. Therefore, biocompatibility and blood circulation time can be significantly improved. Klein et al. recently reported on the ability of polysarcosine to shield siRNA lipoplexes and analyzed the in vivo stability and biodistribution while Koynov and coworkers demonstrated that pSar shielded nanoparticle maintain their size even in human blood. ${ }^{[39,40]}$

Moreover, the unimolecular character of star polymers seems highly beneficial for extracellular stability and results in stable carrier systems without elaborated cross-linking methods. On the one hand, this may prevent the premature release of the cargo in circulation. Initiators with stimuli-responsive moieties, such as disulfides, can trigger destabilization of the system and simultaneously, a release of the cargo in the desired environment. We have already demonstrated the disassembly into the respective polymeric arms in the presence of intracellular glutathione concentrations. ${ }^{[33]}$ Another benefit of the star-like architecture is the possibility to attach functional groups at the end of the arms. Therefore, small well-defined delivery systems with high amount of targeting ligands are feasible and induce their efficient and selective cellular uptake.

In this paper, we present the controlled synthesis of 3-arm and 6-arm polypept(o)ide stars, based on pLys-b-pSar arms as multifunctional siRNA carriers. The focus is set on a more detailed understanding on how the microstructure of starlike polypept(o)ides and their core functionality influences RNAi efficiency in vitro. For the synthesis of these star-like polymers, the controlled living ROP of intensively purified $N$ - $\varepsilon$-t-butyloxycarbonyl-L-lysine NCA and sarcosine NCA was employed, which enables precise control over chain length and results in well-defined star block copolymers. ${ }^{[33,41,42]}$ For detailed characterization of the synthesized star-like polymers, ${ }^{1} \mathrm{H}$ and ${ }^{13} \mathrm{C}$ nuclear magnetic resonance (NMR) spectroscopy, ${ }^{1} \mathrm{H}$ diffusion ordered spectroscopy (DOSY), size exclusion chromatography (SEC), multi-angle dynamic light scattering (DLS), zeta potential (ZP) measurements, and fluorescence correlation spectroscopy (FCS) are utilized for the synthesized star-like polymers. This approach enables the comprehensive evaluation of the nano-sized unimolecular core-shell particles toward their siRNA complexation capability and in vitro gene knockdown.

\section{Results and Discussion}

\subsection{3-Arm and 6-Arm Polypept(o)ide Stars: Controlled Syntheses and Characterization}

The recently developed 3-arm polypept(o)ide stars, consisting of protected pLys(PG)-b-pSar arms, seemed to form a promising basis for the development of siRNA carrier systems. ${ }^{[33]}$ In order to investigate the impact of branching number and core size on the complexation ability of siRNA, a series of 3-arm and 6-arm star polymers with varying functional cores and a hydrophilic, nonionic corona are required. The ring-opening polymerization (ROP) of NCAs enables the facile variation of adjustable block lengths by the monomer to initiator ratio $\mathrm{M} / \mathrm{I}$ and therefore, offering a precise control over core and corona dimensions. For this purpose, purified initiators, bearing three and six primary amine functionalities, were synthesized and applied to the ROP of NCAs. The detailed syntheses of all initiators were described previously. ${ }^{[43]}$ One class of initiators contains disulfide bonds between the core and the individual arms, which provide biodegradability in the intracellular reductive environment and consequently, the disassembly of the polymeric arms can induce the release of siRNA in the cytosol. The complete synthetic pathway for polypept(o)ide based star-like polymers is shown in Scheme 1. In the initial step, 3-arm and 6-arm polypeptide stars were synthesized. For the polypeptide core block, we aimed for chain lengths from 10 up 


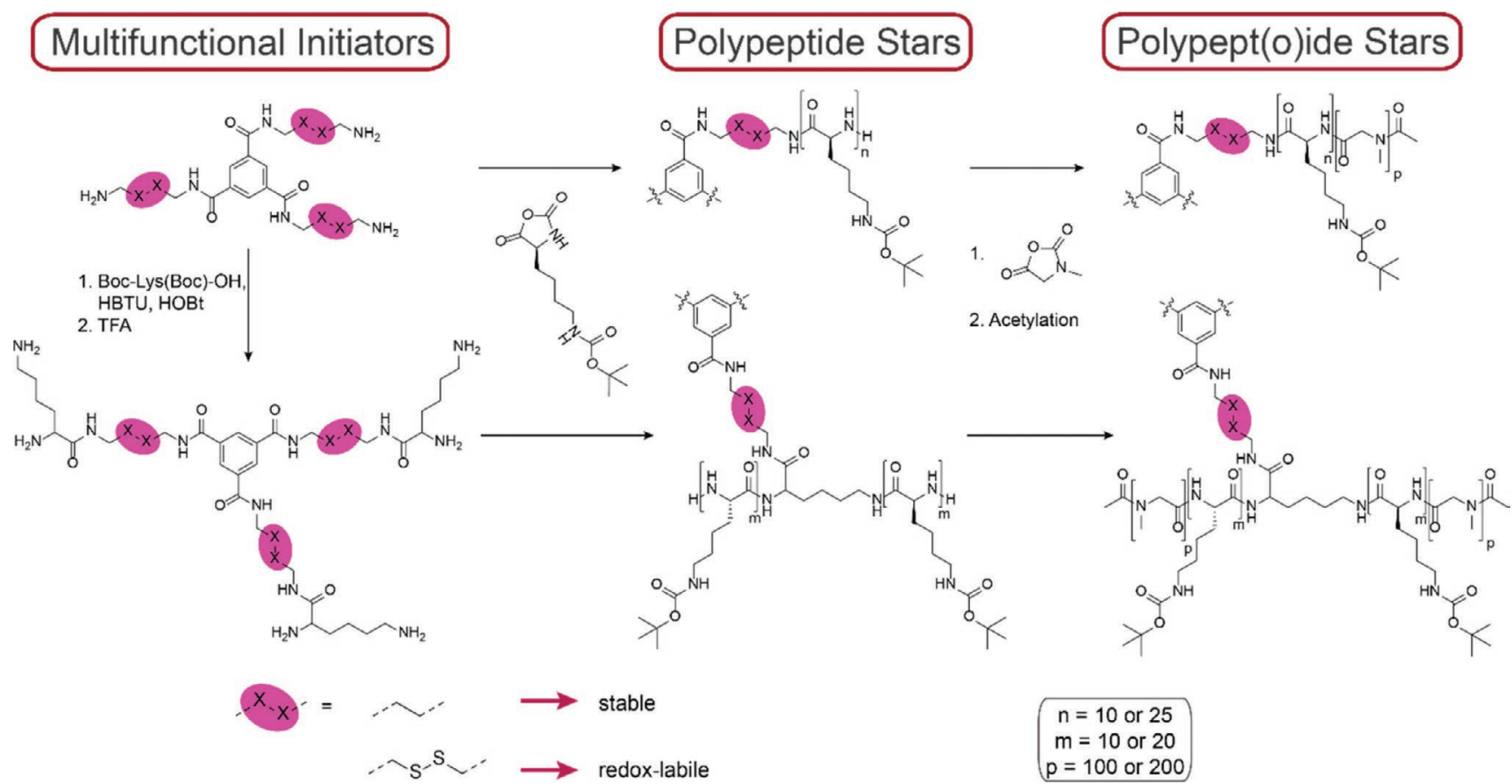

Scheme 1. Synthetic pathway to 3-arm and 6-arm star polymers based on pLys (Boc)-b-pSar.

to 25 units per arm. The $N$ - $\varepsilon$-t-butyloxycarbonyl-L-Lysine NCA (Lys(Boc)NCA) is employed, since the protective groups can be easily cleaved under acidic conditions, while the disulfidecontaining core remains stable. ${ }^{[33]}$ The polymerization of Lys(Boc)NCA was initiated with both types of 3-arm initiators as well as 6-arm initiators in absolute DMF at $0{ }^{\circ} \mathrm{C}$ to ensure a contemporaneous initiation and growth of the polymeric arms.

Characterizations of all polypeptide stars were conducted by ${ }^{1} \mathrm{H}$ NMR and HFIP SEC and the analytical data can be found in Table 1. Desired chain lengths were obtained and verified by ${ }^{1} \mathrm{H}$ NMR with slight deviation of less than $10 \%$. HFIP SEC analyses reveal monomodal molecular weight distributions and narrow to moderate polydispersities $(\nexists=1.1$ to 1.3$)$. Interestingly, butyl- and cystamine-based initiators do not seem to influence the controlled nature of the polymerization since similar molecular weights and dispersity values were observed for both initiator systems, as indicated by respected SEC plots (see Figure 1).

The polypeptide stars were dried in vacuo overnight before storage. Afterward, they were dried for $30 \mathrm{~min}$ under high vacuum right before usage as macroinitiator for the polymerization of the second block. In general, the hydrophilic block length was chosen to be 100 unit per arm to create a proper shielding corona. ${ }^{[35,36]}$ In respect to create a larger polysarcosine corona for enhanced shielding, 200 units per arm were additionally aspired for the disulfide-based 3-arm star polymers. After complete monomer conversion, as verified by FTIR spectroscopy, the polymers were purified and analyzed by ${ }^{1} \mathrm{H}$ NMR and HFIP SEC. In line with the findings of Huesmann et al., the polypeptide cores with degree of polymerization of 10 and 25 for each arm displayed broader SEC elugrams, which can be attributed to the coexistence of peptides in random coil and helical conformation differing substantially in hydrodynamic volume. ${ }^{[3,44]}$

As indicated in Figure 1, a clear shift to lower elution volumes along with a distinct increase in molecular weights is obtained in all cases. Once again, the polypept(o)ide formation proceeded independently of the applied cystamine- or butylbased initiator and lead to desired chain length as determined by ${ }^{1} \mathrm{H}$ NMR. The resulting star polymers displayed a narrow dispersity $(\nexists \leq 1.20)$. PMMA equivalent molecular weights of up to $98 \mathrm{~kg} \mathrm{~mol}^{-1}$ and hydrodynamic radii of up to $14.1 \mathrm{~nm}$ can be achieved in case of 6-arm star polymers (see Table 1). ${ }^{1} \mathrm{H}$ DOSY spectra of all 3-arm and 6-arm polypept(o)ide stars (Figures S28-S33, Supporting Information) reveal that the signals corresponding to the pSar and pLys(Boc) blocks are visible as one single diffusing species, which verified the absence of low molecular weight polymers. These data indicate successful 3-arm and 6-arm polypept(o)ide star formation based on amphiphilic pLys(Boc)-b-pSar arms. The amine end groups of each arm were capped by acetylation with acetic anhydride to further increase the stealth character of polysarcosine. Apart from acetylation, other polymer-analogous reaction such as labeling with dyes can be conducted at the polymer end group. ${ }^{[45]}$

The characterizations of the 3-arm and 6-arm polypept(o)ide star-like polymers by single angle DLS was performed in methanol, since 3 -arm systems aggregated in aqueous solution. ${ }^{[43]}$ The 3-arm polypept(o)ide stars reveal hydrodynamic diameters $\left(D_{\mathrm{h}}\right)$ from around 7 to $12 \mathrm{~nm}$ (see Figure 2A), whereas for 6-arm polypept(o)ides, $D_{\mathrm{h}}$ from 8 to $14 \mathrm{~nm}$ were detected. As expected, the small 6-arm polypept(o)ide stars ((pLys(Boc) ${ }_{10^{-}}$ pSar $\left._{100}\right)_{6}$ ) show slightly decreased sizes in comparison to the 3-arm polypept(o)ides of equal overall chain length (see Table 1). This finding can be attributed to a more compact 
Table 1. Analytical data of 3-arm and 6-arm polypeptide and polypept(o)ide stars.

\begin{tabular}{|c|c|c|c|c|c|}
\hline Polypeptide and polypept(o)ide star & $X_{n}{ }^{\text {a) }}$ (calc.) & $X_{n}{ }^{b)}$ (found) & $M_{\mathrm{n}}^{\mathrm{c})}\left[\mathrm{g} \mathrm{mol}^{-1}\right]$ & $\oslash^{c)}$ & $D_{\mathrm{h}}{ }^{\mathrm{d})}[\mathrm{nm}]$ \\
\hline $\mathrm{SS}\left(\mathrm{pLys}(\mathrm{Boc})_{10}\right)_{3}$ & 30 & 32 & 12600 & 1.18 & 4.1 \\
\hline Butyl (pLys (Boc) 10$)_{3}$ & 30 & 30 & 10000 & 1.26 & 3.9 \\
\hline $\mathrm{SS}\left(\mathrm{pLys}(\mathrm{Boc})_{25}\right)_{3}$ & 75 & 85 & 25000 & 1.16 & 8.5 \\
\hline Butyl (pLys (Boc) 25$)_{3}$ & 75 & 80 & 22600 & 1.17 & 7.5 \\
\hline SS (pLys $\left.(\text { Boc })_{10}\right)_{6}$ & 60 & 65 & 18600 & 1.29 & 4.4 \\
\hline Butyl (pLys (Boc) 10$)_{6}$ & 60 & 71 & 20000 & 1.12 & 4.5 \\
\hline $\mathrm{SS}\left(\mathrm{pLys}(\mathrm{Boc})_{20}\right)_{6}$ & 120 & 129 & 26200 & 1.31 & 6.1 \\
\hline Butyl (plys $\left.(\text { Boc })_{20}\right)_{6}$ & 120 & 122 & 26100 & 1.33 & 5.5 \\
\hline $\mathrm{SS}\left(\mathrm{pLys}(\mathrm{Boc})_{10^{-}-b-\mathrm{pSar}}{ }_{100}\right)_{3}$ & $30-300$ & $32-283$ & 55900 & 1.15 & 6.9 \\
\hline Butyl (pLys (Boc) ${ }_{10}-b$-pSar $\left.{ }_{100}\right)_{3}$ & $30-300$ & $30-286$ & 58100 & 1.14 & 7.6 \\
\hline $\mathrm{SS}\left(\mathrm{pLys}(\mathrm{Boc})_{25}-b-\mathrm{pSar}_{100}\right)_{3}$ & $75-300$ & $85-275$ & 78600 & 1.15 & 10.3 \\
\hline Butyl(pLys (Boc) ${ }_{25}-b$-pSar $\left.{ }_{100}\right)_{3}$ & $75-300$ & $80-278$ & 79800 & 1.15 & 10.1 \\
\hline $\mathrm{SS}\left(\mathrm{pLys}(\mathrm{Boc})_{25}-b-\mathrm{pSar}_{200}\right)_{3}$ & $75-600$ & $85-529$ & 70600 & 1.30 & 10.9 \\
\hline 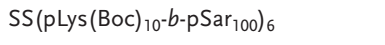 & $60-600$ & $65-556$ & 81700 & 1.20 & 9.1 \\
\hline 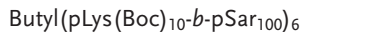 & $60-600$ & $71-551$ & 78800 & 1.13 & 8.2 \\
\hline $\mathrm{SS}$ (pLys $\left(\mathrm{Boc}_{20^{-}-b-\mathrm{pSar}}{ }_{100}\right)_{6}$ & $120-600$ & $129-545$ & 93200 & 1.24 & 14.0 \\
\hline Butyl (pLys (Boc) $)_{20}-b$-pSar $\left.{ }_{100}\right)_{6}$ & $120-600$ & $122-548$ & 97800 & 1.14 & 12.1 \\
\hline
\end{tabular}

a) Calculated degree of polymerization using $\mathrm{X}_{\mathrm{n}}=[\mathrm{M}] /\left[\mathrm{[l]}\right.$; b) Determined by ${ }^{\mathrm{H}} \mathrm{H}$ NMR in DMSO- $\mathrm{d}_{6}$; ${ }^{\mathrm{c}}$ Determined by SEC in HFIP using PMMA standards; ${ }^{\mathrm{d}}$ Determined by dynamic light scattering in methanol at $173^{\circ}$ scattering angle.

structure induced by a higher branching architecture of 6-arm star polymers and are in line with similar observations for 3-arm and 6-arm polypept(o)ide stars based on pGlu(OtBu)-bpSar arms. In addition, angular dependent DLS measurements (from $30^{\circ}$ to $150^{\circ}$ ) were performed for the 6-arm pLys(Boc)-bpSar stars. Figure 2C does not display any angular dependency and similar hydrodynamic radii as obtained by single angle DLS were found.
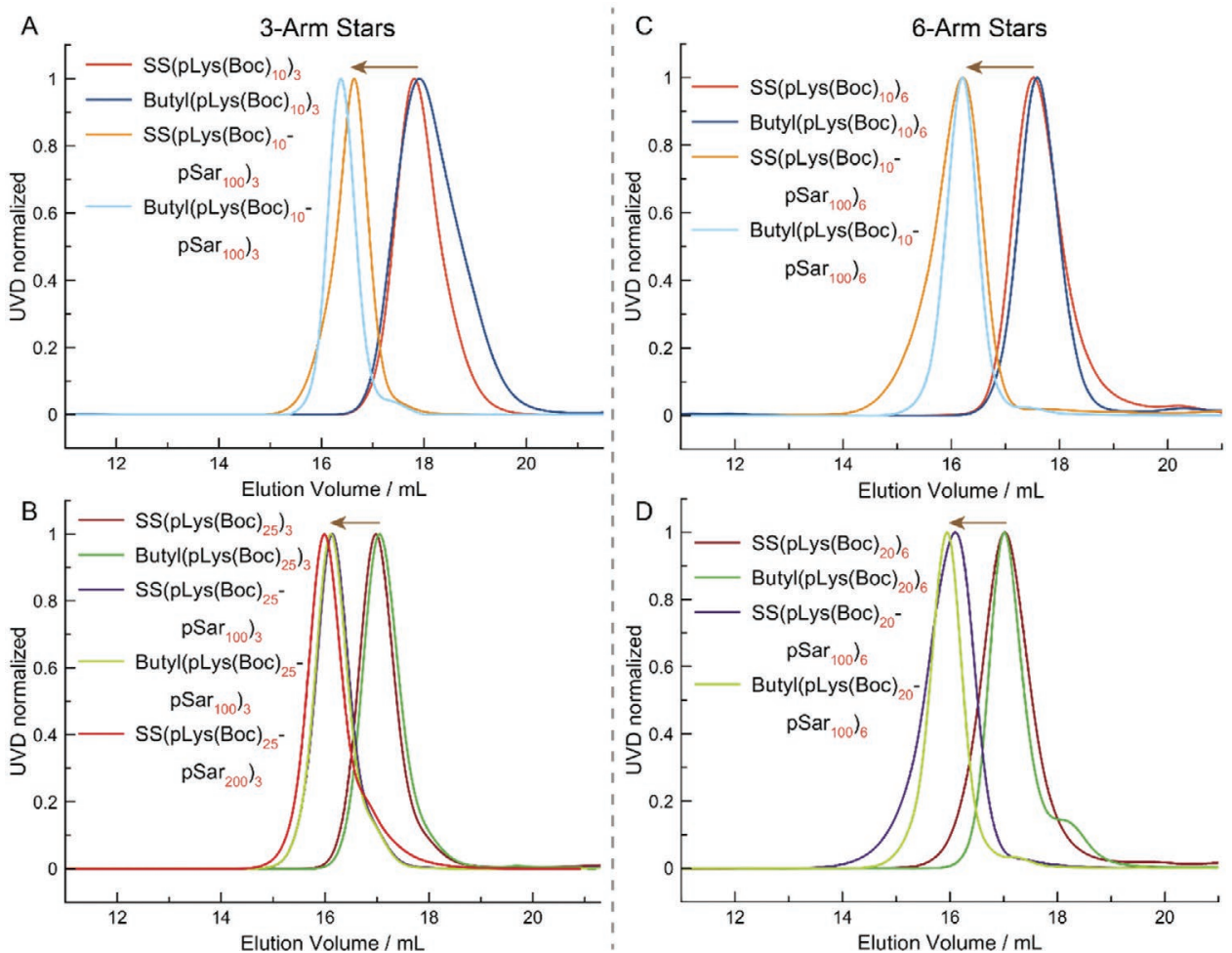

Figure 1. SEC elugrams of A,B) 3-arm and C,D) 6-arm polypeptide stars and arising polypept(o)ide stars. 

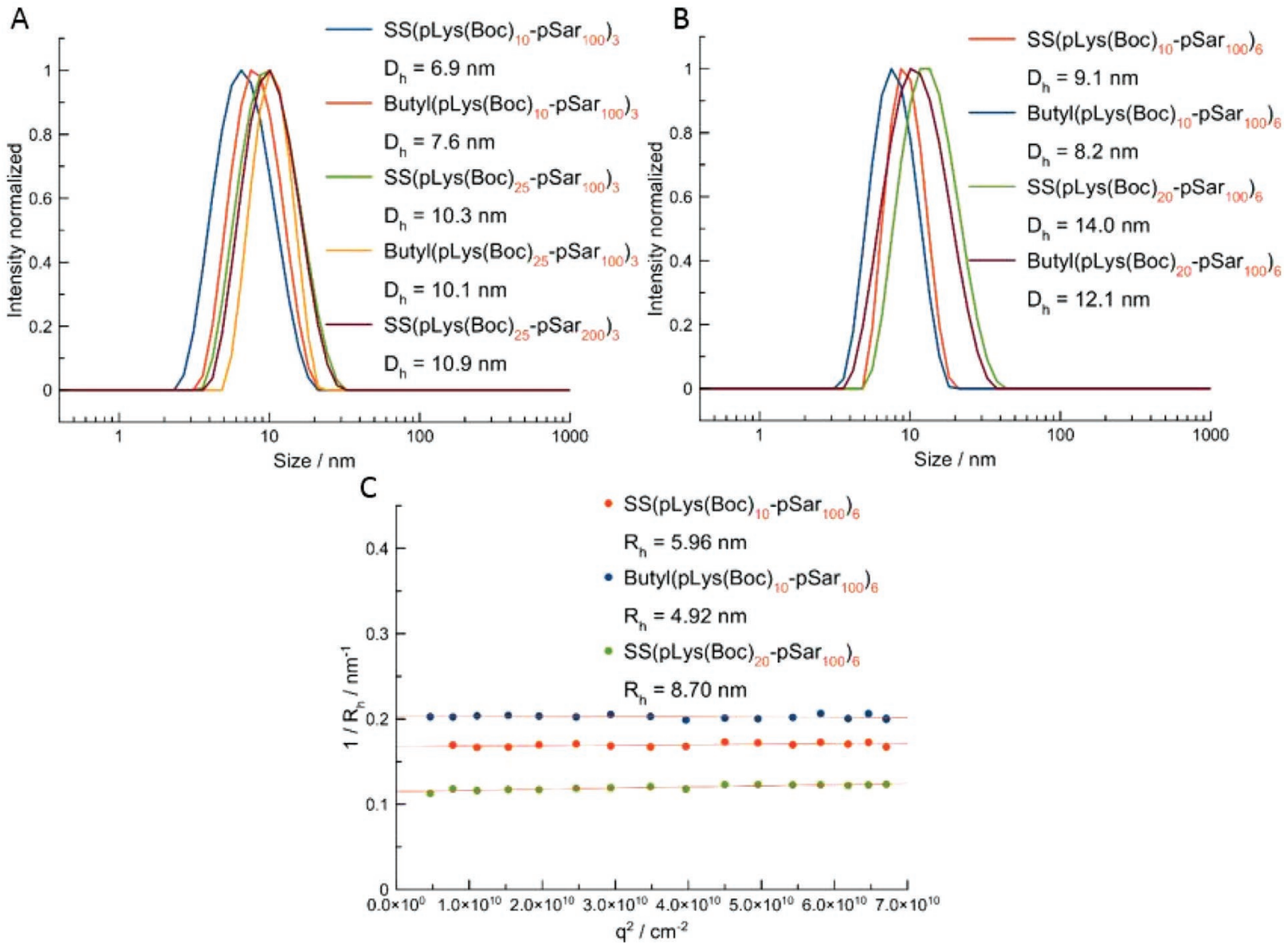

Figure 2. Single angle DLS measurements of A) 3-arm polypept(o)ides and B) 6-arm polypept(o)ides. C) Multi angle dynamic light scattering of 6-arm polypept(o)ide stars.

\subsection{From Hydrophobic to Cationic PeptoStars: Characterization, siRNA Complexation, Core Modification, and Biodegradability}

To yield the desired cationic star polymers, the synthesized 3-arm and 6-arm polypept(o)ide stars need to be deprotected. This can be simply realized via the removal of the Boc protecting groups under acidic conditions, which we already demonstrated. ${ }^{46]}$ The switch of polarity, from a hydrophobic to a cationic core, enables the complexation of small negatively charged molecules, for example, siRNA. Scheme 2 illustrates the formation of cationic 3-arm and 6-arm polypept(o)ide stars. A mixture of $\mathrm{H}_{2} \mathrm{O}$ and trifluoroacetic acid (TFA) (2:1) was applied to achieve complete deprotection within $2 \mathrm{~h}$.

The successful deprotection was verified by ${ }^{1} \mathrm{H}$ NMR spectroscopy and shows the absence of the respective signals of the Boc methyl protons at $1.35 \mathrm{ppm}$ and the Boc amide proton at $6.71 \mathrm{ppm}$ (see Figure 3).

Further characterization of the cationic polypept(o)ide stars was performed by electrophoretic mobility measurements in $10 \mathrm{~mm}$ aqueous $\mathrm{NaCl}$ solution (pH 7.4) to receive information about the zeta potential. The variety of 3-arm and 6-arm polypept(o)ide stars with different core sizes and a comparison among each other enable the investigation of polysarcosine as a shielding corona toward the cationic polypeptidic core. All measured zeta potentials are summarized in Table 2.

In the case of cationic 3-arm polypept(o)ide stars, a distinct shift from zeta potentials of around $6 \mathrm{mV}$ for the smaller peptidic cores (30 lysine units) to $24 \mathrm{mV}$ for the larger cationic cores (75 lysine units) with the same pSar 100 was observed (see Figure 4A), which underlines the obvious fact that the steric shielding effect of a pSar corona decreases with an increase in core size and charge density. Much more interesting was the decrease in zeta potential in case of $\mathrm{SS}\left(\mathrm{pLys}_{25}-b-\mathrm{pSar}_{100}\right)_{3}$ from 25 to $12 \mathrm{mV}$ caused by SS(pLys $25-b$-pSar 200$)_{3}$. This clearly indicates the shielding effect of an increased amount of polysarcosine on a constant cationic polylysine core.

In general, the influence of the polysarcosine corona is more pronounced for 6-arm star polymers (see Figure 4B), since six pSar chains were grafted to the cationic core. Despite of twofold increased peptide core with in total 120 lysine units (( $\mathrm{pLys}_{20}-b$ $\left.\mathrm{pSar}_{100}\right)_{6}$ ), the observed zeta potentials were still in the range of $21 \mathrm{mV}$. The 6-arm star polymers with a total of 60 lysine units showed zeta potentials of around $13 \mathrm{mV}$, which correspond to the cystamine-based 3-arm star (SS( LLys $_{25}-b$ - pSar $\left.\left._{200}\right)_{3}\right)$ with an enlarged polysarcosine corona. This leads to the conclusion that 6-arm star polymers contain a polysarcosine shell with distinct shielding of the cationic cores. 


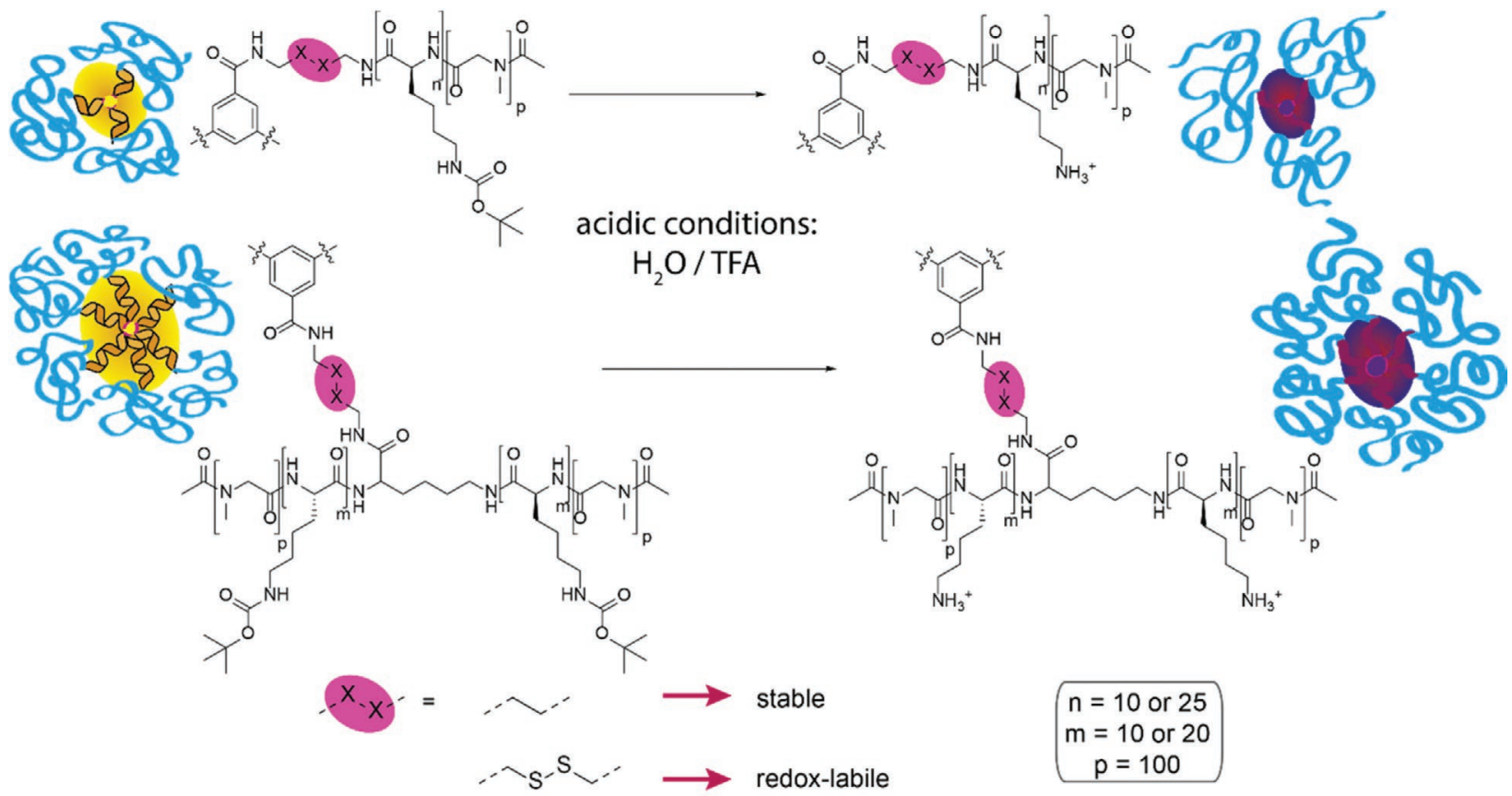

Scheme 2. Synthetic illustration of the formation of cationic PeptoStars.

In the following, the cationic 3-arm and 6-arm polypept(o) ide stars were investigated toward their siRNA complexation capability. For this purpose, agarose gel electrophoresis experiments were performed to investigate the siRNA loading capacity. For each sample, 60 ng siRNA were incubated with increasing amounts of polypept(o)ide stars (weight-to-weight $(\mathrm{w} / \mathrm{w})$ ratios from $1: 1$ to $100: 1)$. Figure $5 \mathrm{~A}$ demonstrates the respective agarose gel of the 3-arm polypept(o)ide star, Butyl $\left(\mathrm{pLys}_{25} \text {-b-pSar }{ }_{100}\right)_{3}$, with a full siRNA retardation at a $\mathrm{w} / \mathrm{w}$ ratio of 10:1. All other complexation experiments of the 3-arm and 6-arm polypept(o)ide stars can be found in Figures S36 and S37, Supporting Information. Unfortunately, the application of $\mathrm{w} / \mathrm{w}$ ratios does not consider the variation of lysine content between different polypept(o)ide stars. For this reason, the weight ratios were converted to $\mathrm{N} / \mathrm{P}$ ratios, with $\mathrm{N}$ for the amount of all positively charged primary amines of the lysine units and P for all negatively charged phosphate groups from siRNA. All calculated N/P ratios can be found in Table 2.

In general, polypept(o)ide stars with increased polylysine content can complex siRNA completely with decreasing N/P ratios. 6-arm polypept(o)ides stars show slightly better complexation capabilities than 3-arm polypept(o)ide stars with similar overall polylysine content, which can be attributed to the higher branched architecture. Interestingly, all siRNA-loaded polypept(o)ide stars were able to migrate to the cathode in the gel at w/w ratios of 30:1 to 100:1 (see Figure 5A and Figures S36 and S37, Supporting Information). This fact indicates an efficient shielding from the polysarcosine corona toward the peptidic core with negatively charged cargo. The zeta potentials of siRNA-loaded polypept(o)ide stars (at w/w ratios of 30:1) were lower than before and close to neutral, compared to unloaded star polymers (see Table 2), which further sustains the rational for the effective shielding of the polysarcosine shell. In addition,

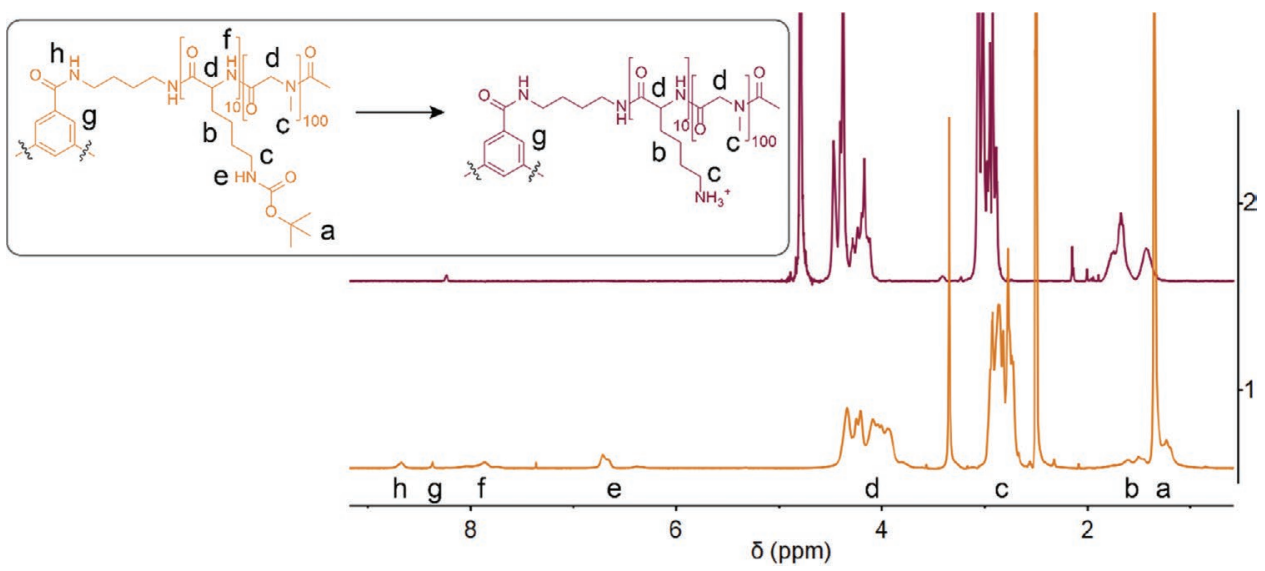

Figure 3. Deprotection of butyl (pLys (Boc) $)_{10}$-b-pSar $\left.{ }_{100}\right)_{3}$ verified by ${ }^{\top} \mathrm{H}$ NMR spectroscopy. 
Table 2. Characteristic data of cationic polypept(o)ide stars.

\begin{tabular}{|c|c|c|c|}
\hline Cationic star polymer & $\begin{array}{c}\text { Zeta potentiala) } \\
{[\mathrm{mV}]}\end{array}$ & $\mathrm{N}: \mathrm{P}_{\text {ratio }}{ }^{\mathrm{b}}$ & $\begin{array}{l}R_{\mathrm{h}}{ }^{c)} \text { of siRNA loaded } \\
\text { particles [nm] }\end{array}$ \\
\hline $\mathrm{SS}\left(\mathrm{pLys}_{10}-b-\mathrm{pSar}_{100}\right)_{3}$ & $7 \pm 4$ & $9: 1$ & $3.0^{\mathrm{d})}$ \\
\hline Butyl (pLys $10-b$-pSar $\left.{ }_{100}\right)_{3}$ & $6 \pm 4$ & $9: 1$ & $3.5^{\mathrm{d})}$ \\
\hline $\mathrm{SS}\left(\mathrm{pLys}_{25}-b-\mathrm{pSar}_{100}\right)_{3}$ & $25 \pm 4$ & $6: 1$ & 7.0 \\
\hline Butyl $\left(\mathrm{pLys}_{25}-b \text {-pSar }{ }_{100}\right)_{3}$ & $23 \pm 4$ & $6: 1$ & $6.0^{\mathrm{d})}$ \\
\hline $\mathrm{SS}\left(\mathrm{pLys}_{25}-b-\mathrm{pSar}_{200}\right)_{3}$ & $12 \pm 4$ & $8: 1$ & n.d. $)^{\text {) }}$ \\
\hline $\mathrm{SS}\left(\mathrm{pLys}_{10}-b-\mathrm{pSar}_{100}\right)_{6}$ & $13 \pm 4$ & $5: 1$ & 6.2 \\
\hline Butyl(pLys ${ }_{10}-b-$ pSar $\left._{100}\right)_{6}$ & $14 \pm 3$ & $5: 1$ & 7.0 \\
\hline $\mathrm{SS}\left(\mathrm{pLys}_{20}-b-\mathrm{pSar} \mathrm{r}_{100}\right)_{6}$ & $22 \pm 4$ & $4: 1$ & 8.8 \\
\hline Butyl $\left(\mathrm{pLys}_{20}-b-\mathrm{pSar}{ }_{100}\right)_{6}$ & $21 \pm 3$ & 3:1 & 8.0 \\
\hline
\end{tabular}

a) Determined by Zeta Sizer in $10 \mathrm{~mm} \mathrm{NaCl}$; b)Calculated from w/w ratios for complete complexation determined by agarose gel electrophoresis; ${ }^{c}$ Determined by FCS with labeled siRNA; d) Measured by FCS without siRNA; ${ }^{\text {e) }}$ n.d. = not determined.

the stability of the siRNA-loaded stars against polyanionic molecules and the ability to release the cargo despite efficient steric shielding was explored by agarose gel electrophoresis. Herein, heparin $\left(14000 \mathrm{~g} \mathrm{~mol}^{-1}\right)$ was chosen as a competitor for siRNA, since heparin is one of the most negatively charged glycosaminoglycan. ${ }^{[47]}$ Figure 5B displays cystamine- and butyl-based 6-arm polypept(o)ide stars at a w/w ratio of 20:1 to ensure complete complexation. In the presence of heparin, complete siRNA release was observed in all cases of polypept(o)ide stars. This shows that a release of the siRNA in the presence of high concentrations of small negatively charged molecules was still feasible and therefore, the synthesized star-like polymers may promote a gene knockdown insight cells. ${ }^{[4]}$ The release, however, is enhanced in the presence of glutathione in the case of disulfide containing star-like polypept(o)ides.

The investigation of the hydrodynamic sizes of polypept(o)ide stars after siRNA loading is another very important aspect to receive information about the developed complexation system. For this purpose, the star samples (SS(pLys $25^{-}$ $b$-pSar $\left.{ }_{100}\right)_{3}, \quad \mathrm{SS}\left(\mathrm{pLys}_{10}-b-\mathrm{pSar}_{100}\right)_{6}, \quad$ butyl $\left(\mathrm{pLys}_{10}-b-\mathrm{pSar}_{100}\right)_{6}$,
$\mathrm{SS}\left(\mathrm{pLys}_{20}-b-\mathrm{pSar}_{100}\right)_{6}$, and butyl( $\left.\mathrm{pLys}_{20}-b-\mathrm{pSar}_{100}\right)_{6}$, respectively) were incubated with Alexa Fluor (AF) 647 labeled siRNA (siRNA-AF647) at respective N/P ratios for complete siRNA complexation. Afterward, fluorescence correlation spectroscopy (FCS) measurements were conducted. Figure 5C and Table 2 summarize the obtained hydrodynamic radii of the siRNA-loaded polypept(o)ide stars. The hydrodynamic radius of $2.4 \mathrm{~nm}$, corresponding to siRNA-AF647, increased to a size range of 6-9 $\mathrm{nm}$ for the different siRNA-loaded polypept(o)ide stars. These findings are well in line with measured hydrodynamic sizes for the protected polypept(o)ide stars, obtained by DLS. As a control, the hydrodynamic radius of AF647-labeled butyl( $\left.\mathrm{pLys}_{25}-b-\mathrm{pSar}_{100}\right)_{3}$ was measured without siRNA and proved to be $6 \mathrm{~nm}$ (see Figure S35, Supporting Information). Labeling of this star polymer was previously performed with Alexa Fluor 647 NHS ester in DMF by attaching the dye to the peptide core. These results reveal a slight increase in size during siRNA complexation but clearly indicate the existence of unimolecular complexes with 1-5 siRNA molecules. Neither FCS nor DLS can detect aggregated siRNA complexes and displays the formation of siRNA containing star-like polypept(o)ides in solution. Furthermore, FCS measurements reveal the presence of an average of 2-3 molecules of siRNA per polypept(o)ide star.

After detailed characterization of the cationic polypept(o)ide stars, modification opportunities of the polypeptide core were investigated. Among labeling with fluorescent dyes, the functional primary amine groups of the lysine residues enable the attachment of further relevant molecules for successful transfection capabilities. Several works emphasize the incorporation of chemical moieties providing a buffer capacity and the ability of protonation in the acidic endosomal environment ("proton sponge effect") and thus, facilitating endosomal escape. ${ }^{[48-50]}$ Histidinylated polylysines or pLys$b$-pHis copolymers have shown to be promising candidates through combination of good buffering characteristics and siRNA complexation. ${ }^{[51]}$ For this reason, the linkage of histidine was realized via a peptide coupling reaction with $N, N^{\prime}$ diBoc-L-histidine and 1-ethyl-3-(3-dimethylaminopropyl)carbodiimide (EDC) as well as 1-hydroxybenzotriazole (HOBt) as carboxyl activating agents.
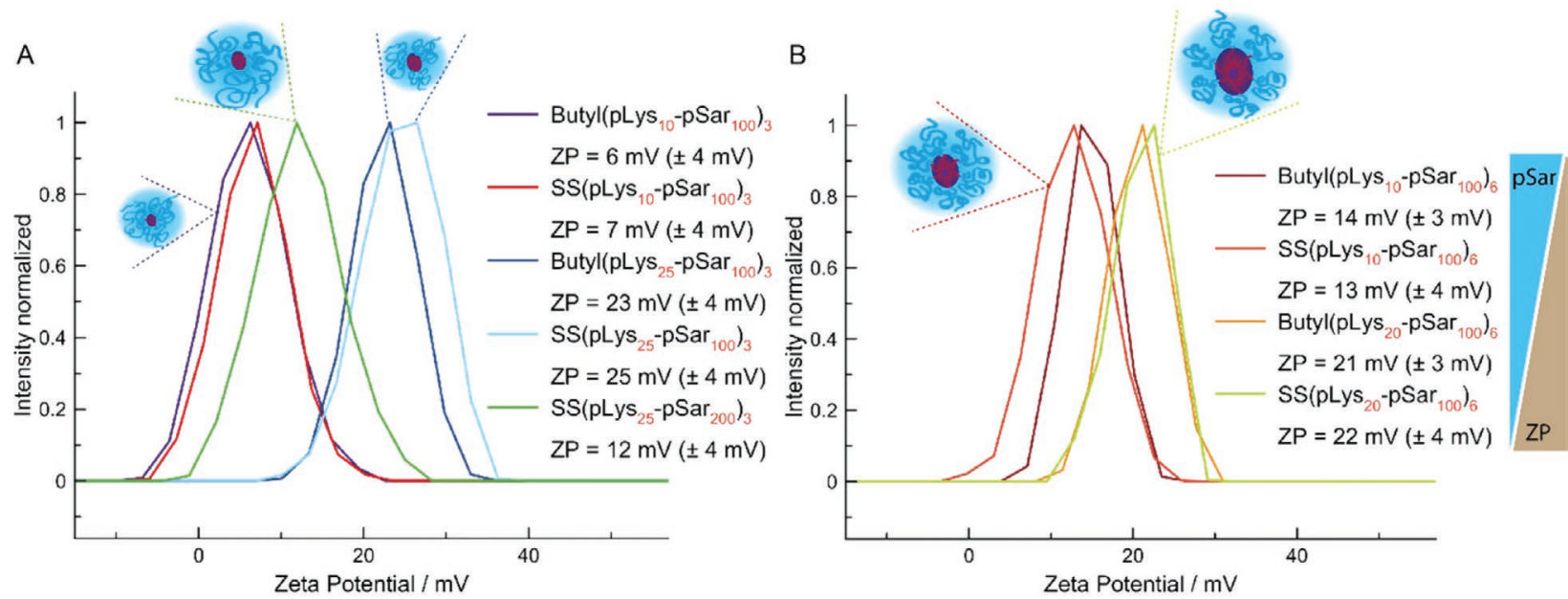

Figure 4. Zeta potentials of cationic 3-arm (A) and 6-arm (B) polypept(o)ide stars (ZP = zeta potential). 

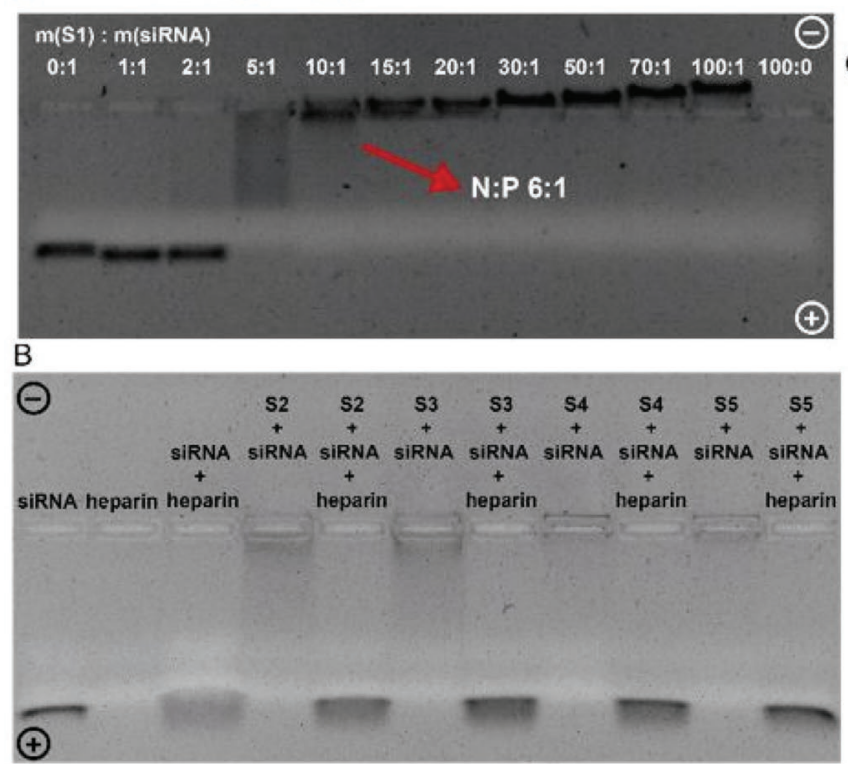

C

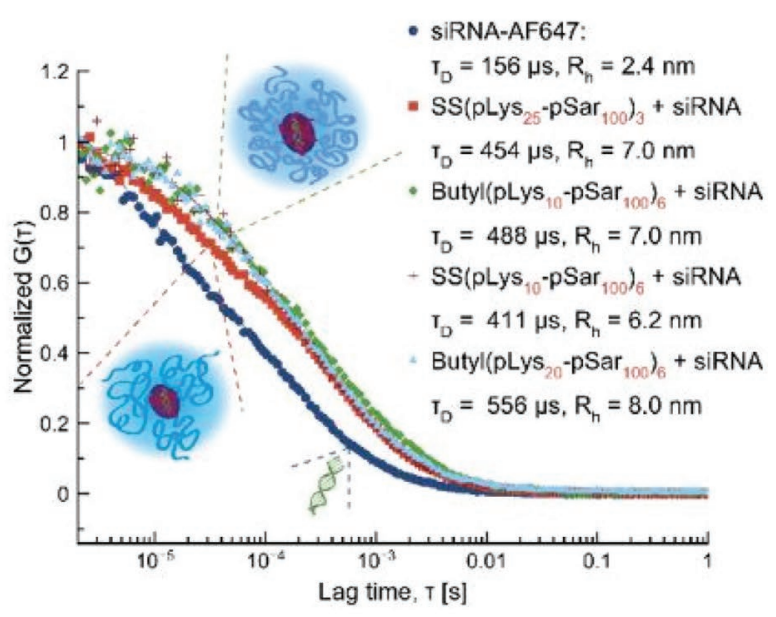

Figure 5. Agarose gel electrophoresis of siRNA loaded 3-arm polypept(o)ide star (A) and 6-arm polypept(o)ide stars with heparin competition (B). FCS measurements of siRNA loaded polypept(o)ide stars (C).

Scheme 3 displays the entire synthetic pathway to introduce histidine moieties within the polylysine blocks. For the cystamine-based 3-arm star polymer (SS( $\left.\left.\mathrm{pLys}_{25}-b-\mathrm{pSar}_{100}\right)_{3}\right)$, the degree of histidinylation was set to be $20 \%$ (referred to the amount of lysine groups), whereas for the butyl-based 6-arm star polymer (butyl( $\mathrm{pLys}_{10}-b$-pSar $\left.\left.{ }_{100}\right)_{6}\right)$, two different degrees, $20 \%$ and $50 \%$, were chosen. After purification by dialysis to remove coupling agents and unreacted diBoc histidine, the starlike polymers were characterized by ${ }^{1} \mathrm{H}$ NMR and ${ }^{1} \mathrm{H}$ DOSY to verify covalent attachment of histidine to the lysine block. ${ }^{1} \mathrm{H}$ DOSY data (see Figures S32 and S33, Supporting Information) clearly demonstrate a successful linkage of diBoc-protected histidines to the polymer, since all corresponding proton signals possess the same diffusion coefficient. Directly afterward, the removal of the Boc protecting groups was performed in $\mathrm{H}_{2} \mathrm{O}$ and TFA (1:1). ${ }^{1} \mathrm{H}$ NMR spectroscopy as well as ${ }^{1} \mathrm{H}$ DOSY displayed complete deprotection by the absent characteristic protective group signal at $1.33 \mathrm{ppm}$. In addition, the determination of the amount of imidazole groups per star polymer can be performed by comparing the signals of the aromatic imidazole ring protons at 6.87 and $7.62 \mathrm{ppm}$ with the initiator signal. Scheme 3B shows a ${ }^{1} \mathrm{H}$ DOSY spectra of the cystamine-based 3 -arm star polymer, which was modified with $16 \%$ histidine. The spectrum further indicates that all signals corresponding to the polymer backbone and the newly introduced imidazole groups are visible as one diffusing species and thereby, confirming the integrity of the modified star polymers.

The siRNA complexation capability of histidinylated star polymers revealed slightly higher N/P ratios in comparison to respective unmodified cationic star polymers in agarose gel electrophoreses (see Figure S38, Supporting Information). This finding was expected, since the imidazole groups $\left(\mathrm{pK}_{\mathrm{a}}=6.1\right)$ are mainly non-charged at neutral $\mathrm{pH}$ and thus hydrophobic. Consequently, a decrease of the overall cationic charge density occurs. ${ }^{[37,52]}$

Prior to the biological evaluation of the cationic polypept(o)ide stars, the focus was set on the biodegradability of the polymeric carrier systems, which is significant for their long-term fate in vivo. In case of cystamine-based polypept(o)ide stars, previous works showed an efficient disassembly of the polymeric arms in the presence of reducing agents such as glutathione. ${ }^{[33]}$ Further degradation of the carrier system, for instance, by enzymatic cleavage, appears beneficial to avoid unwanted accumulation and adverse reactions by design. ${ }^{[53-56]}$ With this regard, 3-arm and 6-arm polypept(o)ide stars were exposed to proteolytic enzymes at $37^{\circ} \mathrm{C}$ and the effects were monitored for 1 week via HFIP SEC. The applied protease is a mixture of endo- and exopeptidases isolated from the bacteria strain Streptomyces griseus, which obtains a broad specificity for various peptides in the presence of calcium ions. ${ }^{[57]}$ The SEC elugrams show in each case a distinct shift to lower molecular weight species after 4 days (see Figure S34, Supporting Information). The species with elution volumes of around $21-20 \mathrm{~mL}$ correspond to the degraded polylysine core. Applying the polysarcosine standard calibration, established by Weber et al., ${ }^{[58]}$ the peak maxima from 17.3 to $17.2 \mathrm{~mL}$ can be clearly assigned to well-defined linear polysarcosine chains with a degree of polymerization of around 90, since the protease mixture lacks the ability to degrade $N$-methylated polypeptoids. However, this further indicates the controlled synthesis of polymeric arms with a contemporaneous initiation and respective growth. Proline iminopeptidase is supposed to cleave $\mathrm{N}$-terminal sarcosine and could 
A

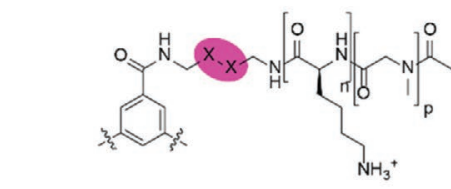
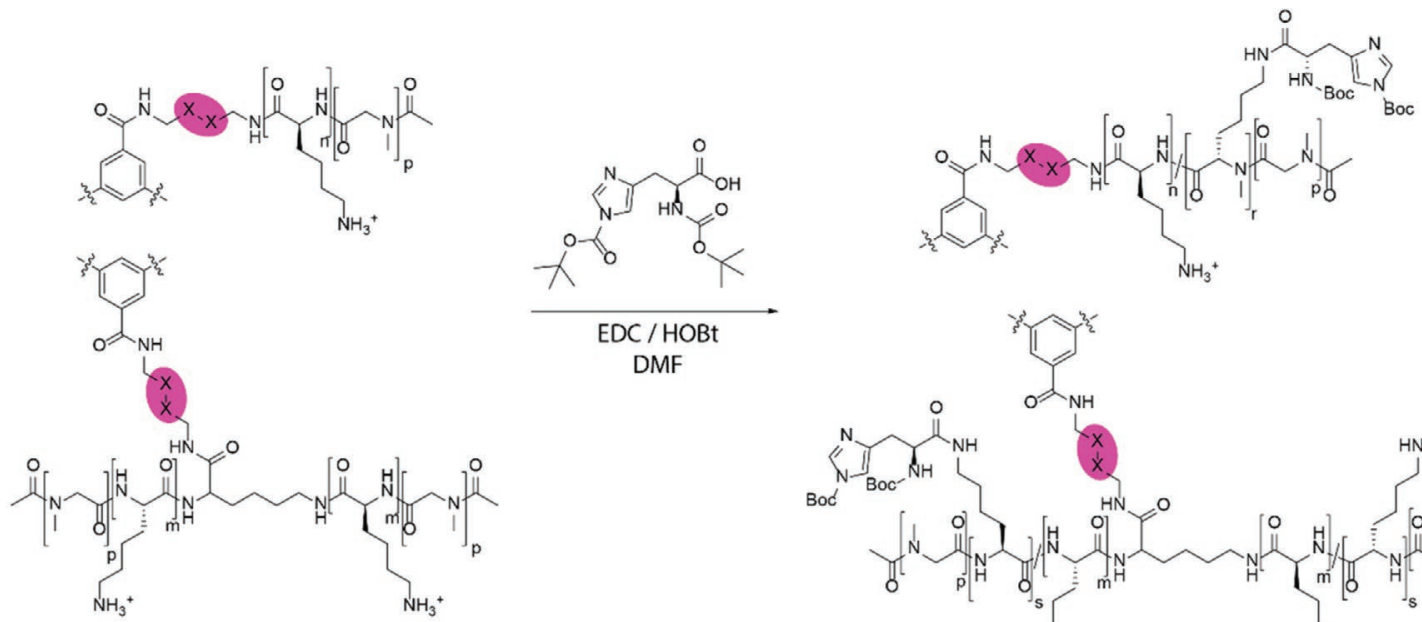

$\mathrm{DMF}$
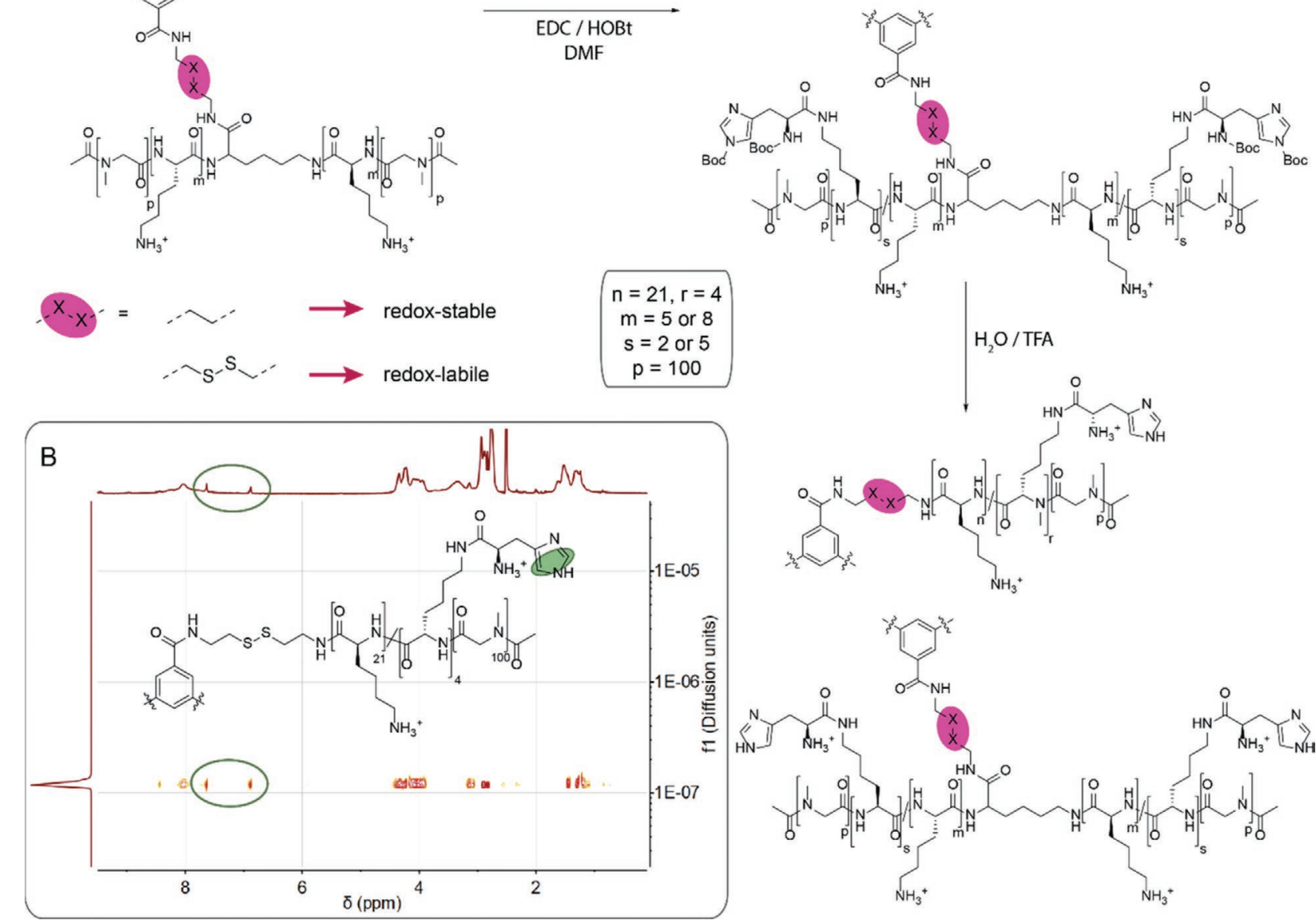

Scheme 3. A) Synthetic pathway of histidine modification for 3-arm and 6-arm polypept(o)ide stars. B) DOSY spectrum of histidine modified cystamine-based 3-arm polypept(o)ide star.

be an appropriate enzymatic alternative. ${ }^{[59]}$ Nevertheless, oxidative degradation of polypeptoids was previously explored by the Luxenhofer group ${ }^{[60]}$ and linear polysarcosine chains posses small hydrodynamic diameters $\left(D_{h}<5 \mathrm{~nm}\right)^{[58]}$ to enable additionally elimination from the body by renal filtration. In conclusion, both cystamine- and butyl-based star-like polymers are degradable under relevant conditions.

\subsection{Biological Evaluation of Cationic PeptoStars: Cytotoxicity, Complement Activation, and Knockdown Potential}

As a first step of biological evaluation of cationic PeptoStars, MTT assays were carried out in Neuro2A cells to evaluate the cytotoxicity of cationic 3-arm (SS/buty $\left(\mathrm{pLys}_{25}-b \text { - } \mathrm{pSar}_{100}\right)_{3}$, $\mathrm{SS}\left(\mathrm{pLys}_{21} / \mathrm{pLysHis}_{4}-b \text { - } \mathrm{pSar}_{100}\right)_{3}$ ) and 6-arm star polymers (SS/

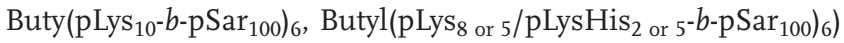

complexed with siRNA. For this purpose, star polymers were applied using a complexation ratio from w/w of 3:1 to 20:1 by using a siRNA (Inf-siGFP and Inf-siCtrl) amount of $250 \mathrm{ng}$. In all biological evaluations, siRNA conjugated to a $\mathrm{pH}$-dependent lytic Inf7-peptide (Inf-siRNA) was used, since it has been shown to be beneficial for transfections in several cases before. ${ }^{[61]}$ The results are summarized in Figure 6 . The cytotoxicity of the unmodified cystamine-based 6-arm star polymer can be further found in the Supporting Information and is likewise the butylbased analogue (see Figure S39, Supporting Information).

In general, all star-like polypept(o)ides did not influence cell viability or only show a minor decrease at highest polymer concentrations tested. The exceptions are the 3-arm star polymers with largest pLys core at highest concentrations which revealed cell viabilities of about $50 \%$ at $\mathrm{w} / \mathrm{w} 20$. The higher cytotoxicity of 3-arm star polymers might be attributed to an insufficient shielding of the cationic core $(\mathrm{ZP}=24 \mathrm{mV})$ compared to 6-arm 


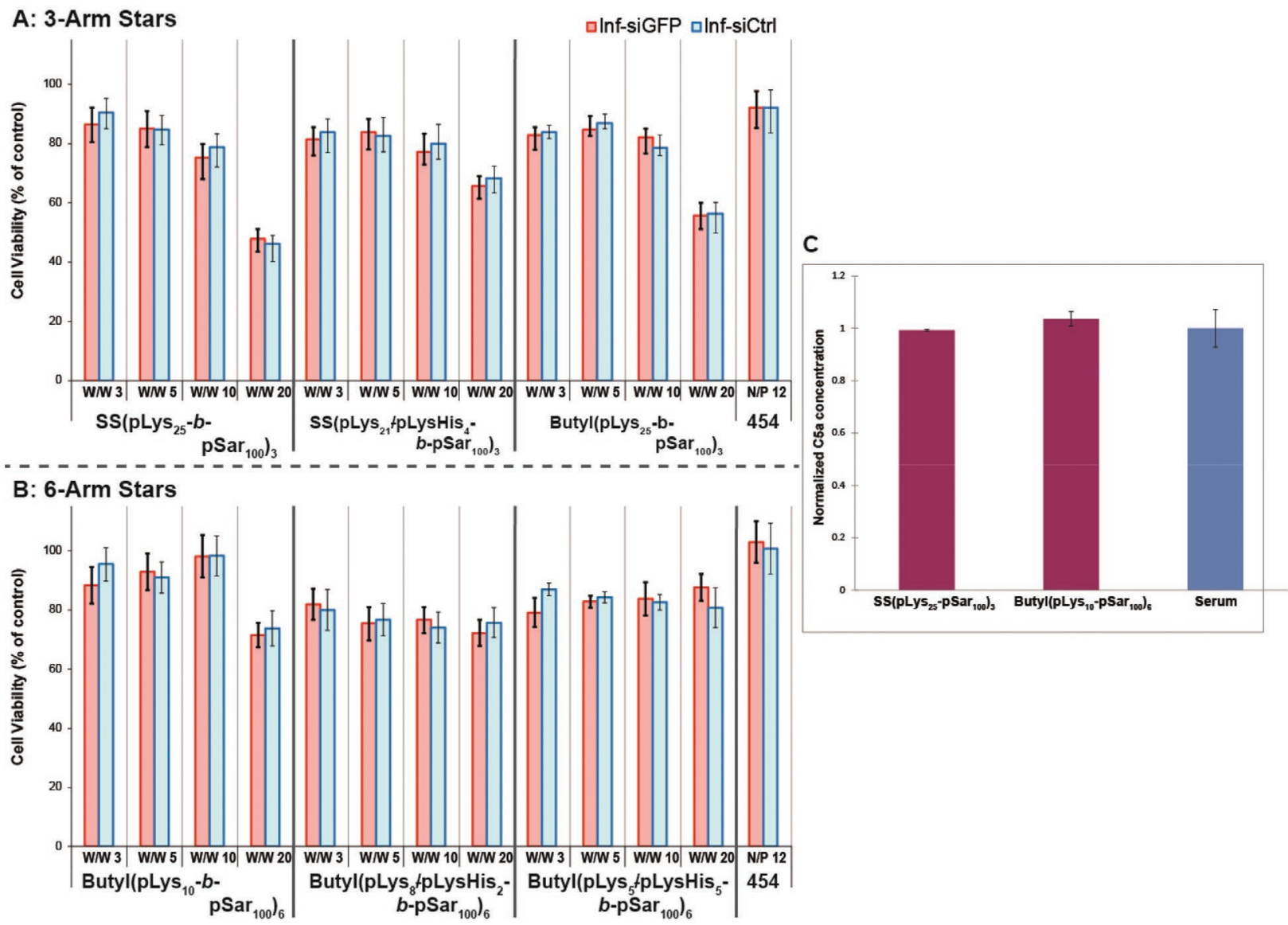

Figure 6. MTT assay of cationic 3-arm (A) and 6-arm (B) polypept(o)ide stars loaded with Inf-siGFP and Inf-siCtrl. Complement activation of cystaminebased 3-arm star and butyl-based 6-arm star (C). W/W describes the complexation ratio (polymer to siRNA).

star polymers (ZP = $14 \mathrm{mV}$, see Table 2). The high amount of cationic lysine units may exhibit high cytotoxicity due to membrane disruptive effects. ${ }^{[62]}$ Differences between cystaminebased and butyl-based polymers have not been observed. In addition, the cell viability in the presence of star polymers with histidinylated peptide cores is constantly around $80 \%$ independent of the polymer concentration. Nevertheless, the cytotoxicity is negligible at relevant $\mathrm{w} / \mathrm{w}$ ratios for full siRNA complexation (w/w 10, see agarose gel electrophorese experiments in the Supporting Information) and none of the star polymers reached the $\mathrm{IC}_{50}$ value for cell viability. Consequently, one can conclude that all star-like polypept(o)ides are well tolerated by Neuro2A cells in vitro.

Besides cell viability, complement activation was also investigated for cationic 3-arm and 6-arm star-like polymers. Therefore, cystamine- and butyl-based star polymers were incubated with human serum for $1 \mathrm{~h}$ at $37^{\circ} \mathrm{C}$ and the concentration of human complement factor $5 \mathrm{a}$ (C5a) was determined. As shown in Figure 6C, distinct increased concentrations of $\mathrm{C} 5 \mathrm{a}$ for cationic star polymers $\left(\mathrm{SS}_{2} \mathrm{pLys}_{25}-b \text { - } \mathrm{pSar}_{100}\right)_{3}$ and Butyl $\left(\mathrm{pLys}_{10^{-}}\right.$ b-pSar $\left.{ }_{100}\right)_{6}$ ) were absent in comparison to human serum itself. Once again, these results confirmed that the cationic polypept(o)idic architectures neither affects the toxicity nor complement activation and thereby, crucial requirements for systemic application as siRNA delivery systems are fulfilled.
In order to determine the knockdown efficiency of the synthesized systems, luciferase assays were subsequently carried out with cationic star polymers consisting of 3-arms and 6-arms and the hystidinylated derivatives thereof. This study enables the evaluation of two different branched architectures with varied modifications and their impact on the corresponding knockdown potential. For the experiments, anti-GFP siRNA conjugated to Inf7-peptide (Inf-siGFP) and control siRNA (Inf-siCtrl), respectively, were complexed with star polymers at increasing polymer to siRNA weight ratio from 3:1 to 20:1 and then applied to Neuro2a/eGFPLuc cells for $48 \mathrm{~h} \cdot{ }^{[61]}$ The cells stably express an eGFP-luciferase fusion protein and eGFP knockdown simultaneously mediates decreased luciferase activity. ${ }^{[63]}$ The oligomer 454, a sequence defined lipooligoamino amide explored by Troiber, Edinger, and Wagner, ${ }^{[64]}$ served as an overall control and demonstrated knockdown potential of around $70 \%$ caused by the Inf-siGFP, whereas the Inf-siCtrl shows a luciferase expression of almost $100 \%$, as expected.

From the results of the luciferase assays, displayed in Figure 7, it is apparent that distinct knockdown effect of any star polymers is absent. The respective results of the cystamine-based 6-arm star polymer can be found in Figure S40, Supporting Information. The Inf-siGFP-loaded 3-arm star polymers (with and without histidine moieties) exclusively showed 

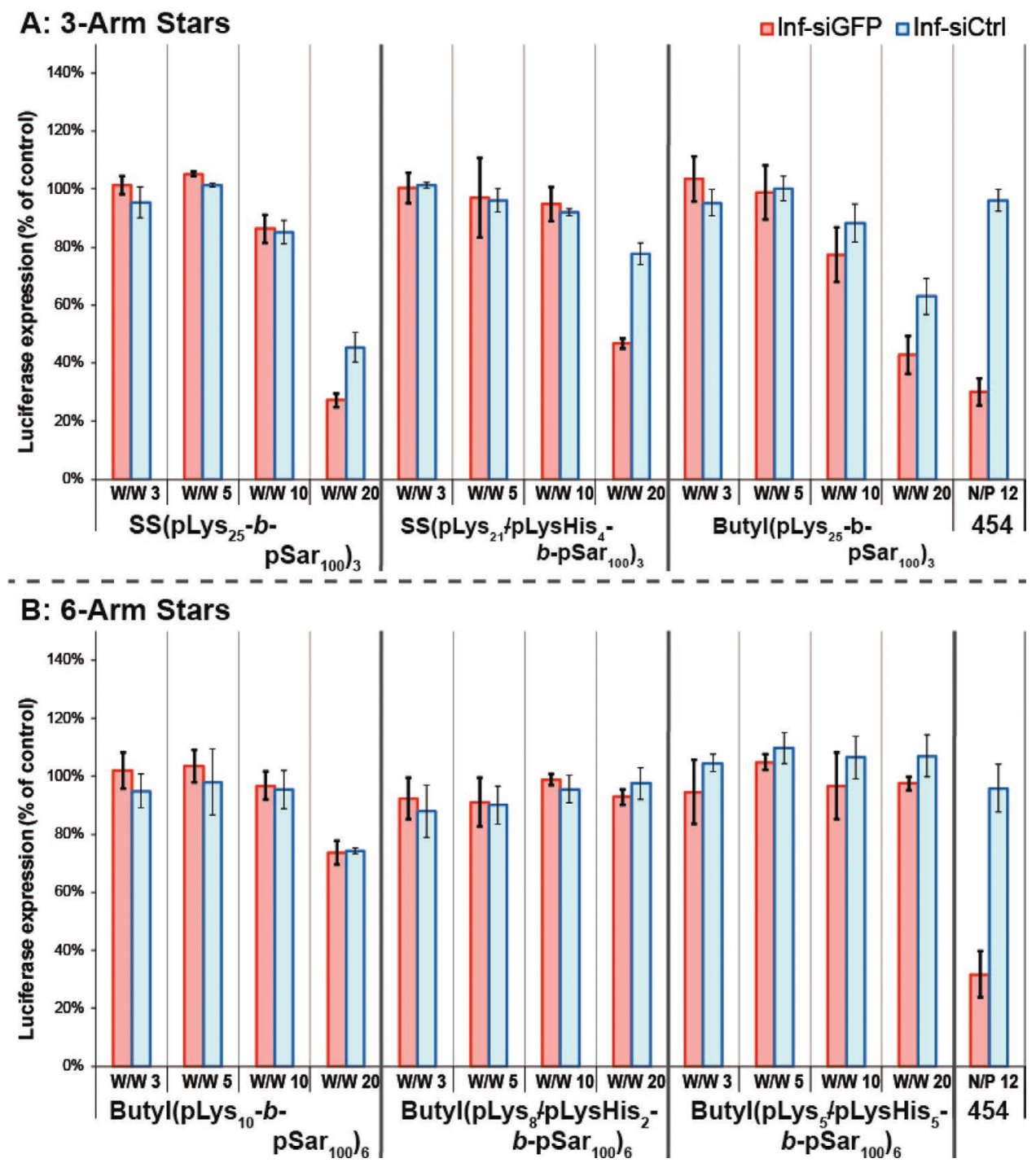

Figure 7. Luciferase assay of 3-arm stars (A) and butyl-based 6-arm stars (B). W/W describes the complexation ratio (polymer to siRNA).

a gene knockdown of about $40 \%$ at highest polymer concentration indicated by the decreased luciferase activity in relation to the respective Inf-siCtrl-loaded 3-arm star polymers (see Figure 7A). Nevertheless, it must be admitted that even the Inf-siCtrl-loaded 3-arm star polymers mediated an unexpected decrease of bioluminescence (around 20-50\%). This might be attributed to the elevated toxicity $(30-50 \%)$ of the 3 -arm star polymers observed via the MTT assay at highest w/w ratios. The histidinylated 3-arm star polymer (SS(pLys ${ }_{21} / \mathrm{pLysHis}_{4}$ $b$-pSar $\left.{ }_{100}\right)_{3}$ ) herein showed the best results with a decrease in cell viability of around $30 \%$ and a knockdown potential of $40 \%$. Unfortunately, the cystamine- and butyl-based 6-arm star polymers do not show any gene knockdown effect. High degrees of histidinylation $(50 \%)$ at highest polymer concentration might demonstrate a minimal decrease of luciferase expression when comparing to the Inf-siCtrl (see Figure 7B). Since we expect that both the endosomolytic Inf7-peptide and histidinylation should be efficient to enforce endosomal release after successful cellular uptake and thereby enhancing gene silencing, the reason for the low gene knockdown efficiency presumably is not inefficient endosomal escape or release of siRNA. Obviously, the highly efficient steric shielding of PeptoStars by their pSar corona reduces cellular interaction and internalization. Since we know that 6-arm star-like polypept(o)ides display reduced cellular uptake even in vitro arising from the stealthlike properties of the pSar shell, the observed insufficient knockdown may be overcome by the use of ligands targeting cell surface receptors of the target cells. Further investigations toward the modification of cationic star polymers are necessary to achieve a stronger luciferase knockdown and enable the translation to relevant disease models.

\section{Conclusion}

In this work, we developed multifunctional unimolecular carrier systems for siRNA delivery based on pLys-b-pSar star architectures. The controlled living ROP facilitated the precise 
synthesis of a variety of well-defined 3-arm and 6-arm star polymers consisting of different sized cationic cores and a hydrophilic corona with efficient shielding properties. Therefore, a comprehensive evaluation of the impact of branching and size toward the complexation ability of small negatively charged siRNA was enabled.

Detailed size characterization by DLS and FCS confirmed the presence of uniform small core-shell structure revealing hydrodynamic diameter from 7.0 to $17.6 \mathrm{~nm}$. Even complexation of siRNA led to unimolecular carrier systems without distinct size increment and the complete absence of aggregation. Especially, 6-arm star polymers demonstrated high complexation capabilities (N/P from 5:1 to 3:1) in combination with low zeta potentials and hence showing a proper shielding from the branched sarcosine corona toward the cationic core. In addition, the core-cross-linked character of the star polymers assures stable siRNA-loaded carrier systems with extra destabilizing features in the presence of increased glutathione concentrations.

The functional polylysine core further enabled the facile modification with different degrees of histidine moieties for enhanced endosomal escape. Interestingly, the cationic polypept(o)idic stars were generally well tolerated by Neuro2A cells and did not induce any complement activation in human serum. In this regard, the developed strategy enables the synthesis of multifunctional core-shell particles as siRNA carriers with multiple opportunities for modification. The special feature is the independent adjustment of the degree of functional cores as well as the charge shielding corona and simultaneously gaining small-sized unimolecular carrier systems. Nevertheless, the attachment of suitable ligands seems to be necessary to enhance cellular uptake and achieve successful RNAi in vitro and in vivo.

\section{Experimental Section}

Materials and Methods: Sarcosine and solvents were purchased from Sigma Aldrich. $\mathrm{H}-\mathrm{L}-\mathrm{Lys}-\mathrm{OH} * \mathrm{HCl}$ was purchased from Iris Biotech and $\mathrm{H}$-L-Lys $(\mathrm{Boc})-\mathrm{OH}$ was purchased from Carbolutions. The dye Alexa Fluor 647 NHS ester was purchased from Thermo Fisher Scientific. THF and $n$-hexane were dried over $\mathrm{Na} / \mathrm{K}$ prior to use. DMF was purchased from Acros (99.8\%, Extra Dry), dried over $\mathrm{CaH}_{2}$ and molecular sieves $(4 \AA)$, and fractionally distilled in $\mathrm{N}_{2}$ atmosphere. Freshly distilled DMF was stored at $-80{ }^{\circ} \mathrm{C}$ under exclusion of light. Before use, DMF was degassed under vacuum for at least $20 \mathrm{~min}$ to remove residual dimethylamine. Diphosgene was purchased from Alfa Aesar and used without further purification. 1,3,5-Benzenetricarbonyl trichloride was purchased from Acros. N-Boc-1,4-butanediamine was purchased from Sigma Aldrich and N-Boc cystamine from Chem-Impex International. Millipore water was prepared using a MILLI-Q Reference A+ System. Water was used at a resistivity of $18.2 \mathrm{M} \Omega \mathrm{cm}^{-1}$ and total organic carbon of $<5 \mathrm{ppm} .{ }^{1} \mathrm{H}$ and ${ }^{13} \mathrm{C}$ NMR spectra were recorded on a Bruker AV 400 at room temperature. Spectra were calibrated using the solvent signals $\left(\delta=2.500 \mathrm{ppm}\right.$ for DMSO-d $6, \delta=7.260 \mathrm{ppm}$ for $\left.\mathrm{CDCl}_{3}\right)$. The degree of polymerization $\left(X_{n}\right)$ was calculated using ${ }^{1} \mathrm{H}$ NMR spectroscopy by comparing the integrals of initiator peaks and an average of integrals of methyl group and $\alpha$-protons for pSar, and for pLys(Boc), an average of polymer protons.

Infrared spectroscopy was performed on a Jasco FT/IR-4100 with an ATR sampling accessory (MIRacle, Pike Technologies) using 16 scans per measurement. IR spectra were analyzed using Spectra Manager 2.0 (Jasco). NCA polymerization was monitored by FT-IR spectroscopy.
Polymerization was judged to be complete when NCA associated carbonyl peaks at 1853 and $1786 \mathrm{~cm}^{-1}$ had vanished. Size exclusion chromatography (SEC) in hexafluoroisopropanol (HFIP) was performed with $3 \mathrm{~g} \mathrm{~L}^{-1}$ potassium trifluoroacetate at $40{ }^{\circ} \mathrm{C}$. The columns were packed with modified silica (PFG columns, particle size: $7 \mu \mathrm{m}$, porosity: 100 and $1000 \AA$ ). A refractive index detector (G 1362A RID, Jasco) and a UV/vis detector (UV-2075 Plus, JASCO) were used to detect the polymer. Molecular weights were calculated using calibration performed with PMMA standards (Polymer Standards Services $\mathrm{GmbH}$ ). As the internal standard, toluene was used. Melting points were determined on Mettler Toledo FP62 melting point apparatus at a heating rate of $5{ }^{\circ} \mathrm{C} \mathrm{min}^{-1}$.

DLS measurements were first performed at $25{ }^{\circ} \mathrm{C}$ using a Malvern Zetasizer NanoZS with a $633 \mathrm{~nm} \mathrm{He} / \mathrm{Ne}$ Laser at a fixed scattering angle of $173^{\circ}$. Besides, further DLS measurements were performed using a Uniphase $\mathrm{He} / \mathrm{Ne}$ Laser $(I=632.8 \mathrm{~nm}, 22 \mathrm{~mW})$, an ALV-SP125 Goniometer, an ALV/High QE APDAvalanche photo diode with fiber optical detection, an ALV 5000/E/PCl-correlator and a Lauda RC-6 thermostat unit at $20{ }^{\circ} \mathrm{C}$. Angular dependent measurements were carried out in the range $30^{\circ} \leq q \leq 150^{\circ}$ in typically $15^{\circ}$ steps.

3-Arm Initiator Synthesis: The synthesis of the two trimeric amine initiators were adapted from literature and modified. ${ }^{65]}$

Boc-Protected Cystamine-Based Initiator: $\quad N^{1}, N^{3}, N^{5}$-Tris(2-((2Tert-Butyloxycarbonyl-Aminoethyl) Disulfanyl) Ethyl) Benzene-1, 3, 5Tricarboxamide: N-(Tert-Butyloxycarbonyl)cystamine $(116 \mathrm{mg}, 0.46 \mathrm{mmol}$, $3.3 \mathrm{eq}$ ) was weighed into a flame-dried two-neck round-bottom flask and dissolved in $2 \mathrm{~mL}$ abs. THF. Freshly distilled $\mathrm{N}, \mathrm{N}$-diisopropylethylamine (DIPEA) (78 $\mu \mathrm{L}, 0.46 \mathrm{mmol}, 3.3 \mathrm{eq}$ ) was added and stirred for $15 \mathrm{~min}$ at room temperature. 1,3,5-benzenetricarbonyl trichloride $(36 \mathrm{mg}$, $0.14 \mathrm{mmol}, 1 \mathrm{eq}$ ) was weighed into another flame-dried round-bottom flask and dissolved in $1 \mathrm{~mL}$ abs. THF. The trichloride solution was slowly added to the $\mathrm{N}$-(tert-butyloxycarbonyl)cystamine mixture via syringe. The progress of the reaction was monitored by $T L C\left(R_{f}=0.53\right.$, EtOAc/PE $10 \%)$. After $4 \mathrm{~h}$, the solvent was evaporated in vacuo and the residue was dissolved in ethyl acetate. The organic phase was sequentially washed with milliQ water, $1 \mathrm{~m}$ hydrochloric acid, and saturated sodium bicarbonate solution. The organic phase was dried over magnesium sulfate and concentrated in vacuo. Purification by column chromatography yielded the desired product as a white foam $(92.1 \mathrm{mg}$, $0.1 \mathrm{mmol}, 72 \%)$.

${ }^{1} \mathrm{H}$ NMR $\left(400 \mathrm{MHz}, \mathrm{CDCl}_{3}\right) \delta[\mathrm{ppm}]=1.38\left(\mathrm{~s}, \mathrm{br}, 27 \mathrm{H},-\mathrm{C}\left(\mathrm{CH}_{3}\right)_{3}\right)$, $2.83\left(\mathrm{t}, 3_{\mathrm{H}, H}=6.40 \mathrm{~Hz}, 6 \mathrm{H},-\mathrm{SCH}_{2} \mathrm{CH}_{2} \mathrm{NHBoc}\right), 2.95\left(\mathrm{t},{ }^{3} \mathrm{~J}_{\mathrm{H}, \mathrm{H}}=6.00 \mathrm{~Hz}\right.$, $6 \mathrm{H},-\mathrm{SCH}_{2} \mathrm{CH}_{2} \mathrm{NHCOC}$ ), 3.45 (br, $\left.6 \mathrm{H},-\mathrm{CH}_{2} \mathrm{NHBoc}\right), 3.74-3.78(\mathrm{~m}$ $\left.6 \mathrm{H},-\mathrm{CH}_{2} \mathrm{NHCOC}\right), 5.22$ (br, $\left.3 \mathrm{H},-\mathrm{NHBoc}\right), 7.58$ (br, $3 \mathrm{H},-\mathrm{NHCOC}$ ), $8.27(\mathrm{~s}, 3 \mathrm{H},=\mathrm{CH})$;

${ }^{13} \mathrm{C}$ NMR $\left(400 \mathrm{MHz}, \mathrm{CDCl}_{3}\right) \delta[\mathrm{ppm}]=28.5\left(-\mathrm{C}\left(\mathrm{CH}_{3}\right)_{3}\right), 38.1$ (- $\left.\mathrm{SCH}_{2} \mathrm{CH}_{2} \mathrm{NHCOC}\right), 38.3$ (- $\left.\mathrm{SCH}_{2} \mathrm{CH}_{2} \mathrm{NHBoc}\right), 39.4\left(-\mathrm{CH}_{2} \mathrm{NHCOC}\right)$ $39.7\left(-\mathrm{CH}_{2} \mathrm{NHBOC}\right), 79.8\left(-\mathrm{C}\left(\mathrm{CH}_{3}\right)_{3}\right), 128.7(=\mathrm{CH}), 135.3(=\mathrm{CCONH})$, 156.2 (-NHCOO), $166.6(=\mathrm{CCONH})$.

Boc-Protected Butyl-Based Initiator: $N^{1}, N^{3}, N^{5}$-Tris (2-(2-Tert-ButyloxycarbonylAminobutyl)) Benzene-1,3,5-Tricarboxamide: $\quad \mathrm{N}$-(tert-Butyloxycarbonyl)-1,4butanediamine $(121 \mu \mathrm{L}, 0.63 \mathrm{mmol}, 3.3 \mathrm{eq})$ was dissolved in $2 \mathrm{~mL}$ abs. dichloromethane. Freshly distilled DIPEA (107 $\mu \mathrm{L}, 0.63 \mathrm{mmol}, 3.3 \mathrm{eq})$ was added and stirred for $15 \mathrm{~min}$ at room temperature. 1,3,5-benzenetricarbonyl trichloride $(51 \mathrm{mg}, 0.19 \mathrm{mmol}, 1 \mathrm{eq}$ ) was weighed into a flame-dried round-bottom flask and was dissolved in $2 \mathrm{~mL}$ abs. dichloromethane. The trichloride solution was slowly added to the $N$-(tert-butyloxycarbonyl)1,4-butanediamine mixture via syringe. The progress of the reaction was monitored by TLC $\left(R_{f}=0.59\right.$, EtOAc/MeOH $\left.10 \%\right)$. After $4 \mathrm{~h}$, the solvent was evaporated in vacuo and the residue was dissolved in chloroform. The organic phase was sequentially washed with milliQ water, $1 \mathrm{~m}$ hydrochloric acid, and saturated sodium bicarbonate solution. The organic phase was dried over magnesium sulfate and concentrated in vacuo. $126.5 \mathrm{mg}$ of the pure product was obtained $(0.17 \mathrm{mmol}, 92 \%)$.

${ }^{1} \mathrm{H}$ NMR $\left(400 \mathrm{MHz}, \mathrm{CDCl}_{3}\right) \delta[\mathrm{ppm}]=1.37\left(\mathrm{~s}, 27 \mathrm{H},-\mathrm{C}\left(\mathrm{CH}_{3}\right)_{3}\right)$, 1.59-1.67 (m, 12 $\left.\mathrm{H},-\mathrm{CH}_{2} \mathrm{CH}_{2} \mathrm{CH}_{2} \mathrm{CH}_{2}\right), 3.13-3.17$ (m, 6H, $\left.\mathrm{CH}_{2} \mathrm{NHBoc}\right)$, 3.43-3.48 (m, 6H, CH $\left.\mathrm{CH}_{2} \mathrm{NHCO}\right), 5.11\left(\mathrm{t}, 3_{\mathrm{H}, \mathrm{H}}=8.00 \mathrm{~Hz}, 3 \mathrm{H},-\mathrm{NHBoc}\right)$, 7.63 (s, br, $3 \mathrm{H},-\mathrm{NHCOC}), 7.93(\mathrm{~s}, 3 \mathrm{H},=\mathrm{CH})$; 
${ }^{13} \mathrm{C}$ NMR $\left(400 \mathrm{MHz}, \mathrm{CDCl}_{3}\right) \delta[\mathrm{ppm}]=26.9\left(-\mathrm{CH}_{2} \mathrm{CH}_{2} \mathrm{CH}_{2} \mathrm{CH}_{2}\right)$, $28.6\left(-\mathrm{C}\left(\mathrm{CH}_{3}\right)_{3}\right), 40.0 \quad\left(-\mathrm{CH}_{2} \mathrm{NHCOC}\right), \quad 40.5 \quad\left(-\mathrm{CH}_{2} \mathrm{NHBOc}\right), \quad 79.3$ $\left(-\mathrm{C}\left(\mathrm{CH}_{3}\right)_{3}\right), 128.2(=\mathrm{CH}), 135.7(=\mathrm{CCONH}), 156.5(-\mathrm{NHCOO}), 167.1$ $(=\mathrm{CCONH})$.

Deprotection: TFA Salt of $N^{1}, N^{3}, N^{5}$-Tris (2-((2-Aminoethyl)Disulfanyl) Ethyl)Benzene-1,3,5-Tricarboxamide: $40 \mathrm{mg}(0.04 \mathrm{mmol})$ of the Bocprotected cystamine based initiator was dissolved in abs. dichloromethane $(1 \mathrm{~mL})$ and $0.5 \mathrm{~mL}$ TFA was added. The reaction was stirred under argon for $60 \mathrm{~min}$ and the completion of the reaction was monitored by TLC. The solvents were evaporated in vacuo. The TFA salt of the initiator $(38 \mathrm{mg}$, $0.04 \mathrm{mmol}$ ) was obtained in quantitative yields and dried under vacuum.

${ }^{1} \mathrm{H} \quad \mathrm{NMR}\left(400 \mathrm{MHz}, \mathrm{D}_{2} \mathrm{O}\right) \delta[\mathrm{ppm}]=3.00-3.03(\mathrm{~m}, 12 \mathrm{H}$, $\mathrm{CH}_{2} \mathrm{CH}_{2} \mathrm{SSCH}_{2} \mathrm{CH}_{2}$ ), 3.38 (t, $\int_{H, H}=8.00 \mathrm{~Hz}, 2 \mathrm{H}, \mathrm{CH}_{2} \mathrm{NHBoc}$ ), 3.78 $\left(\mathrm{t}, 3_{\mathrm{H}, \mathrm{H}}=8.00 \mathrm{~Hz}, 2 \mathrm{H}, \mathrm{CH}_{2} \mathrm{NHCO}\right), 8.28(\mathrm{~s}, 3 \mathrm{H},=\mathrm{CH})$.

TFA Salt of $N^{1}, N^{3}, N^{5}$-Tris(2-(2-Aminobutyl)) Benzene-1,3,5-Tricarboxamide: $20.4 \mathrm{mg}(0.03 \mathrm{mmol})$ of the Boc-protected butyl based initiator was dissolved in abs. dichloromethane $(1 \mathrm{~mL})$ and $0.5 \mathrm{~mL}$ TFA was added. The reaction was stirred under argon for $60 \mathrm{~min}$ and the completion of the reaction was monitored by TLC. The solvents were evaporated in vacuo. The TFA salt of the initiator $(22.7 \mathrm{mg}, 0.03 \mathrm{mmol})$ was obtained in quantitative yields and dried under vacuum.

${ }^{1} \mathrm{H}$ NMR $\left(400 \mathrm{MHz}, \mathrm{D}_{2} \mathrm{O}\right) \delta[\mathrm{ppm}]=1.67-1.79(\mathrm{~m}, 12 \mathrm{H}$, $\mathrm{CH}_{2} \mathrm{CH}_{2} \mathrm{SSCH}_{2} \mathrm{CH}_{2}$ ), 3.04 (t, 3/H,H $=8.00 \mathrm{~Hz}, 2 \mathrm{H}, \mathrm{CH}_{2} \mathrm{NHBoc}$ ), 3.46 (t, $\left.3_{H, H}=8.00 \mathrm{~Hz}, 2 \mathrm{H}, \mathrm{CH}_{2} \mathrm{NHCO}\right), 8.24(\mathrm{~s}, 3 \mathrm{H},=\mathrm{CH})$.

6-Arm Initiator Synthesis: Boc-Lys(Boc)-OH: The synthesis of BocLys(Boc)- $\mathrm{OH}$ was adapted from literature and modified. ${ }^{[66]}$

L-Lysine hydrochloride $(6.1 \mathrm{~g}, 0.033 \mathrm{~mol}, 1 \mathrm{eq})$ was weighed into a round-bottom flask and dissolved in $80 \mathrm{~mL} \mathrm{H} \mathrm{H}_{2} \mathrm{O} . \mathrm{NaHCO}_{3}(8.42 \mathrm{~g}$, $0.100 \mathrm{~mol}, 3 \mathrm{eq}$ ) was added and the suspension was stirred and cooled to $0{ }^{\circ} \mathrm{C}$. Di-tert-butylpyrocarbonate $\left(\mathrm{Boc}_{2} \mathrm{O}, 14.4 \mathrm{~g}, 0.066 \mathrm{~mol}, 2 \mathrm{eq}\right)$ in $50 \mathrm{~mL}$ tetrahydrofuran (THF) was added dropwise over a period of $30 \mathrm{~min}$ via a dropping funnel. The reaction mixture was stirred at room temperature for $12 \mathrm{~h}$. After $12 \mathrm{~h}$, the same amount of $\mathrm{Boc}_{2} \mathrm{O}(14.4 \mathrm{~g}$, $0.066 \mathrm{~mol}, 2 \mathrm{eq}$ ) was added again at $0{ }^{\circ} \mathrm{C}$ and stirred for additional $12 \mathrm{~h}$. The completion of the reaction was monitored by TLC $\left(R_{f}=0.54\right.$, EtOAc) and THF was removed under reduced pressure. The aqueous layer was washed twice with diethyl ether, acidified to $\mathrm{pH} 4-5$ using citric acid solution, and afterward extracted extensively with dichloromethane. The organic layer was washed with brine, dried over anhydrous $\mathrm{Na}_{2} \mathrm{SO}_{4}$, and concentrated in vacuo. The pure product was obtained as a white foam and further drying under high vacuum resulted in $9.7 \mathrm{~g}(0.028 \mathrm{~mol}, 85 \%)$ of a white solid.

${ }^{1} \mathrm{H}$ NMR $\left(400 \mathrm{MHz}\right.$, DMSO- $\left.\mathrm{d}_{6}\right) \delta[\mathrm{ppm}]=1.37\left(\mathrm{~m}, 22 \mathrm{H}, 2 \mathrm{x}-\mathrm{C}\left(\mathrm{CH}_{3}\right)_{3}\right.$, $\left.-\mathrm{CH}_{2} \mathrm{CH}_{2} \mathrm{CH}_{2} \mathrm{CH}_{2}-\right)$, 1.51-1.62 (m, 2H, $\left.-\mathrm{CHCH}_{2} \mathrm{CH}_{2}-\right)$, 2.87-2.89 (m, $\left.2 \mathrm{H},-\mathrm{NHCH}_{2} \mathrm{CH}_{2}-\right), 3.78-3.83\left(\mathrm{~m}, 1 \mathrm{H},-\mathrm{CHCH}_{2} \mathrm{CH}_{2}-\right), 6.65-6.77(\mathrm{~m}$, $\left.1 \mathrm{H},-\mathrm{CONHCH}_{2} \mathrm{CH}_{2}-\right), 6.99-7.01(\mathrm{~m}, 1 \mathrm{H},-\mathrm{CHNHCO}-), 12.39(\mathrm{~s}, 1 \mathrm{H}$, $\mathrm{COOH})$.

Cystamine-Based 6-Arm Initiator: Boc-Lys(Boc)-OH (162.8 mg, $0.47 \mathrm{mmol}, 6 \mathrm{eq})$, together with $N, N, N^{\prime}, N^{\prime}$-tetramethyl-O- $(1 \mathrm{H}$ benzotriazol-1-yl)uronium hexafluorophosphate (HBTU, $193.4 \mathrm{mg}$, $0.51 \mathrm{mmol}, 6.5 \mathrm{eq})$ and 1-hydroxybenzotriazole ( $\mathrm{HOBt}, 68.9 \mathrm{mg}$, $0.51 \mathrm{mmol}, 6.5 \mathrm{eq})$ were weighed into a Schlenk flask and dissolved in $2 \mathrm{~mL}$ abs. DMF. DIPEA (132.65 $\mu \mathrm{L}, 0.78 \mathrm{mmol}, 10 \mathrm{eq})$ was directly added and the mixture was stirred for $30 \mathrm{~min}$ at $0{ }^{\circ} \mathrm{C}$. In another Schlenk flask, cystamine-3-arm initiator $(74.8 \mathrm{mg}, 0.078 \mathrm{mmol}, 1 \mathrm{eq}$ ) were dissolved in $1 \mathrm{~mL}$ abs. DMF, DIPEA (46.4 $\mu \mathrm{L}, 0.273 \mathrm{mmol}$, $3.5 \mathrm{eq})$ were added and stirred for $30 \mathrm{~min}$. The di-Boc-lysine mixture was subsequently added to the 3-arm initiator solution and stirred at room temperature for 2 days. Afterward, the reaction mixture was poured into $0.5 \mathrm{M} \mathrm{KHSO}_{4}$ and extracted three times with ethyl acetate. The organic layers were combined and subsequently washed with $\mathrm{H}_{2} \mathrm{O}$ and brine. After passage through anhydrous $\mathrm{Na}_{2} \mathrm{SO}_{4}$, the organic layer was evaporated under reduced pressure. The residue was purified using column chromatography $\left(R_{f}=0.55\right.$, EtOAc/MeOH $\left.1 \%\right)$ to yield $81.1 \mathrm{mg}$ $(0.05 \mathrm{mmol}, 64 \%)$ of the pure product.

${ }^{1} \mathrm{H}$ NMR $\left(400 \mathrm{MHz}, \mathrm{CD}_{3} \mathrm{OD}\right) \delta[\mathrm{ppm}]=1.25-1.51(\mathrm{~m}, 66 \mathrm{H}$, $\left.-\mathrm{C}\left(\mathrm{CH}_{3}\right)_{3},-\mathrm{CH}_{2} \mathrm{CH}_{2} \mathrm{CH}_{2} \mathrm{CH}_{2}-\right)$, 1.53-1.77 (m, 6H, $\left.-\mathrm{CHCH}_{2} \mathrm{CH}_{2}-\right)$, 2.85-2.88 $\left(\mathrm{m}, 6 \mathrm{H},-\mathrm{SCH}_{2} \mathrm{CH}_{2} \mathrm{NHCOC}-\right), 2.96-3.04(\mathrm{~m}, 12 \mathrm{H}$,
$\left.-\mathrm{SCH}_{2} \mathrm{CH}_{2} \mathrm{NHCOC}=\mathrm{C}-, \quad-\mathrm{CH}_{2} \mathrm{CH}_{2} \mathrm{NHBoc}-\right), \quad 3.41-3.46 \quad(\mathrm{~m}, \quad 6 \mathrm{H}$, $\left.-\mathrm{CH}_{2} \mathrm{NHCOC}-\right)$, 3.72-3.75 (m, 6H, $\left.-\mathrm{CH}_{2} \mathrm{NHCOC}=\mathrm{C}-\right), 3.89-4.00(\mathrm{~m}$, $\left.3 \mathrm{H},-\mathrm{CHCH}_{2} \mathrm{CH}_{2}-\right), 8.46(\mathrm{~s}, 3 \mathrm{H},=\mathrm{CH})$.

${ }^{13} \mathrm{C} \mathrm{NMR}\left(400 \mathrm{MHz}, \mathrm{CD}_{3} \mathrm{OD}\right) \delta[\mathrm{ppm}]=24.24\left(-\mathrm{CHCH}_{2} \mathrm{CH}_{2} \mathrm{CH}_{2}-\right)$, $28.85\left(-\mathrm{C}\left(\mathrm{CH}_{3}\right)_{3}\right), 30.62\left(-\mathrm{CHCH}_{2} \mathrm{CH}_{2} \mathrm{CH}_{2}-\right), 33.15\left(-\mathrm{CHCH}_{2} \mathrm{CH}_{2} \mathrm{CH}_{2}-\right)$, $38.47 \quad\left(=\mathrm{CCONHCH}_{2} \mathrm{CH}_{2} \mathrm{~S}-\right), \quad 38.51 \quad\left(-\mathrm{SCH}_{2} \mathrm{CH}_{2} \mathrm{NH}\right), \quad 39.55$ (- $\left.\mathrm{SCH}_{2} \mathrm{CH}_{2} \mathrm{NHCOCH}-\right), \quad 40.50 \quad\left(=\mathrm{CCONHCH}_{2} \mathrm{CH}_{2} \mathrm{~S}-\right), \quad 41.04$ (- $\left.\mathrm{CH}_{2} \mathrm{CH}_{2} \mathrm{CH}_{2} \mathrm{NHBoc}\right), 56.21$ (- $\left.\mathrm{COCHNH}-\right), 79.85\left(-\mathrm{C}\left(\mathrm{CH}_{3}\right)_{3}\right), 80.61$ $\left(-\mathrm{C}\left(\mathrm{CH}_{3}\right)_{3}\right), 130.16(=\mathrm{CH}), 136.61 \quad(=\mathrm{C}=), 157.86(-\mathrm{NHCOCHNHBoc})$, 158.55 (=CCONH-), $168.68\left(-\mathrm{NHCOOC}\left(\mathrm{CH}_{3}\right)_{3}\right), 175.47$ (-NHCOOC-).

Butpl-Based 6-Arm Initiator: Boc-Lys(Boc)-OH $(644.3 \mathrm{mg}, 1.86 \mathrm{mmol}$, $6 \mathrm{eq})$, together with HBTU $(766.1 \mathrm{mg}, 2.02 \mathrm{mmol}, 6.5 \mathrm{eq})$ and $\mathrm{HOBt}$ (272.9 mg, $2.02 \mathrm{mmol}, 6.5 \mathrm{eq}$ ) were weighed into a Schlenk flask and dissolved in $4 \mathrm{~mL}$ abs. DMF. DIPEA $(0.53 \mathrm{~mL}, 3.1 \mathrm{mmol}, 10 \mathrm{eq})$ was directly added and the mixture was stirred for $30 \mathrm{~min}$ at $0{ }^{\circ} \mathrm{C}$. In another Schlenk flask, butyl-based 3-arm initiator $(240 \mathrm{mg}, 0.31 \mathrm{mmol}$, 1 eq) were dissolved in $0.8 \mathrm{~mL}$ abs. DMF, DIPEA $(0.19 \mathrm{~mL}, 1.1 \mathrm{mmol}$, $3.5 \mathrm{eq})$ was added and stirred for $30 \mathrm{~min}$. The di-Boc-lysine mixture was subsequently added to the 3 -arm initiator solution and stirred at room temperature for 2 days. Afterward, the reaction mixture was poured into $0.5 \mathrm{M} \mathrm{KHSO}_{4}$ and extracted three times with ethyl acetate. The organic layers were combined and subsequently washed with $\mathrm{H}_{2} \mathrm{O}$ and brine. After passage through anhydrous $\mathrm{Na}_{2} \mathrm{SO}_{4}$, the organic layer was evaporated under reduced pressure. The residue was purified using column chromatography $\left(R_{f}=0.45, \mathrm{EtOAc} / \mathrm{MeOH} 10 \%\right)$ to yield $363.4 \mathrm{mg}(0.26 \mathrm{mmol}, 84 \%)$ of the pure product.

${ }^{1} \mathrm{H}$ NMR $\left(400 \mathrm{MHz}, \mathrm{CD}_{3} \mathrm{OD}\right) \delta[\mathrm{ppm}]=1.28-1.50(\mathrm{~m}, 66 \mathrm{H}$, $\left.-\mathrm{C}\left(\mathrm{CH}_{3}\right)_{3},-\mathrm{CH}_{2} \mathrm{CH}_{2} \mathrm{CH}_{2} \mathrm{CH}_{2}-\right)$, 1.54-1.76 (m, $18 \mathrm{H},-\mathrm{CHCH}_{2} \mathrm{CH}_{2}-$, $\left.-\mathrm{NHCH}_{2} \mathrm{CH}_{2} \mathrm{CH}_{2} \mathrm{CH}_{2} \mathrm{NH}-\right)$, 3.00-3.04 (m, 6H, $\left.-\mathrm{CH}_{2} \mathrm{CH}_{2} \mathrm{NHBoc}^{-}\right)$, 3.18$3.28\left(\mathrm{~m}, 6 \mathrm{H},-\mathrm{CH}_{2} \mathrm{NHCOCH}-\right) 3.41-3.45\left(\mathrm{~m}, 6 \mathrm{H},-\mathrm{CH}_{2} \mathrm{NHCOC}=\mathrm{C}-\right)$, 3.84-3.97 (m, $\left.3 \mathrm{H},-\mathrm{CHCH}_{2} \mathrm{CH}_{2}-\right), 8.40(\mathrm{~s}, 3 \mathrm{H},=\mathrm{CH})$.

${ }^{13} \mathrm{C}$ NMR $\left(400 \mathrm{MHz}, \mathrm{CD}_{3} \mathrm{OD}\right) \delta[\mathrm{ppm}]=24.25\left(-\mathrm{CHCH}_{2} \mathrm{CH}_{2} \mathrm{CH}_{2}-\right)$, $27.67\left(-\mathrm{CH}_{2} \mathrm{CH}_{2} \mathrm{CH}_{2} \mathrm{CH}_{2} \mathrm{~N}-\right)$, $27.83\left(-\mathrm{NHCH}_{2} \mathrm{CH}_{2} \mathrm{CH}_{2} \mathrm{CH}_{2} \mathrm{NH}-\right)$, 28.83 $\left(-\mathrm{C}\left(\mathrm{CH}_{3}\right)_{3}\right), \quad 30.61 \quad\left(-\mathrm{CH}_{2} \mathrm{CH}_{2} \mathrm{CH}_{2} \mathrm{NHBoc}\right), 33.14\left(-\mathrm{CHCH}_{2} \mathrm{CH}_{2}-\right)$, $39.96\left(-\mathrm{CH}_{2} \mathrm{CH}_{2} \mathrm{NHCOCH}-\right), 40.74 \quad\left(-\mathrm{CH}_{2} \mathrm{CH}_{2} \mathrm{NHCOC}=\mathrm{C}-\right), 41.00$ $\left(-\mathrm{CH}_{2} \mathrm{CH}_{2} \mathrm{~N}-\right), \quad 56.31 \quad(-\mathrm{COCHNH}-), \quad 79.83 \quad\left(-\mathrm{C}\left(\mathrm{CH}_{3}\right)_{3}\right), \quad 80.57$ $\left(-\mathrm{C}\left(\mathrm{CH}_{3}\right)_{3}\right), 129.86(=\mathrm{CH}), 136.78(=\mathrm{C}=), 175.82(-\mathrm{NHCOCHNHBoc})$, $158.56(=\mathrm{CCONH}-), 168.61\left(-\mathrm{NHCOOC}\left(\mathrm{CH}_{3}\right)_{3}\right), 175.30$ (-NHCOOC-$)$.

Deprotection: TFA Salt of Cystamine-Based 6-Arm Initiator: $86 \mathrm{mg}$ $(0.05 \mathrm{mmol})$ of the Boc-protected cystamine-based 6-arm initiator was weighed into a round-bottom flask and dissolved in dry dichloromethane (1 $\mathrm{mL}$ ). $0.5 \mathrm{~mL}$ TFA was subsequently added. The reaction was stirred under argon for $2 \mathrm{~h}$ and the completion of the reaction was monitored by TLC. The solvents were evaporated in vacuo. The TFA salt of the initiator (127.1 mg, $0.05 \mathrm{mmol}$ ) was obtained in quantitative yields and dried under vacuum.

${ }^{1} \mathrm{H} \quad \mathrm{NMR}\left(400 \mathrm{MHz}, \mathrm{D}_{2} \mathrm{O}\right) \delta[\mathrm{ppm}]=1.41-1.48(\mathrm{~m}, 6 \mathrm{H}$, $\left.-\mathrm{CHCH}_{2} \mathrm{CH}_{2} \mathrm{CH}_{2}-\right)$, 1.65-1.73(m, 6H, $\left.-\mathrm{CH}_{2} \mathrm{CH}_{2} \mathrm{CH}_{2} \mathrm{NH}_{2}\right), 1.86-1.93$ ( $\left.\mathrm{m}, 6 \mathrm{H},-\mathrm{CHCH}_{2} \mathrm{CH}_{2}-\right)$, 2.83-2.94 (m, 6H, $\left.-\mathrm{SCH}_{2} \mathrm{CH}_{2} \mathrm{NHCO}\right), 2.95-$ $3.05\left(\mathrm{~m}, 12 \mathrm{H},-\mathrm{CH}_{2} \mathrm{CH}_{2} \mathrm{NH}_{2}=\mathrm{CCONHCH}_{2} \mathrm{CH}_{2} \mathrm{~S}-\right), 3.48-3.58(\mathrm{~m}, 3 \mathrm{H}$, $\left.-\mathrm{SCH}_{2} \mathrm{CH}_{2} \mathrm{NHCO}-\right)$, 3.63-3.72 (m, 3H, $\left.-\mathrm{SCH}_{2} \mathrm{CH}_{2} \mathrm{NHCO}-\right)$, 3.76$3.79\left(\mathrm{~m}, 6 \mathrm{H},=\mathrm{CCONHCH} \mathrm{CH}_{2} \mathrm{~S}-\right), 3.92-3.98\left(\mathrm{~m}, 3 \mathrm{H},-\mathrm{COCHNH}{ }_{2}\right)$, $8.29(\mathrm{~s}, 3 \mathrm{H},=\mathrm{CH})$.

${ }^{13} \mathrm{C}$ NMR $\left(400 \mathrm{MHz}, \mathrm{D}_{2} \mathrm{O}\right) \delta[\mathrm{ppm}]=21.27\left(-\mathrm{CH}_{2} \mathrm{CH}_{2} \mathrm{CH}_{2} \mathrm{NH}_{2}\right)$, $26.34 \quad\left(-\mathrm{CH}_{2} \mathrm{CH}_{2} \mathrm{CH}_{2} \mathrm{NH}_{2}\right), \quad 30.38 \quad\left(-\mathrm{CHCH}_{2} \mathrm{CH}_{2}-\right), \quad 36.24$ $\left(-\mathrm{SCH}_{2} \mathrm{CH}_{2} \mathrm{NHCOCH}-\right), \quad 36.44 \quad\left(-\mathrm{SCH}_{2} \mathrm{CH}_{2} \mathrm{NHCOC}=\mathrm{C}-\right), \quad 37.76$ $\left(-\mathrm{CH}_{2} \mathrm{CH}_{2} \mathrm{~N}\right), 38.87\left(-\mathrm{CH}_{2} \mathrm{CH}_{2} \mathrm{NHCOC}=\mathrm{C}-\right), 38.96\left(-\mathrm{CH}_{2} \mathrm{CH}_{2} \mathrm{NH}_{2}\right)$, $53.04 \quad(-\mathrm{COCHNH}-), \quad 134.97 \quad(=\mathrm{CH}), \quad 142.76 \quad(=\mathrm{C}=), \quad 169.03$ $\left(-\mathrm{NHCOCHNH}_{2}\right), 169.71$ (=CCONH-$)$.

TFA Salt of Butyl-Based 6-Arm Initiator: $170 \mathrm{mg}(0.12 \mathrm{mmol})$ of the Boc-protected butyl-based 6-arm initiator was weighed into a roundbottom flask and dissolved in dry dichloromethane $(1 \mathrm{~mL}) .0 .5 \mathrm{~mL}$ TFA was subsequently added. The reaction was stirred under argon for $2 \mathrm{~h}$ and the completion of the reaction was monitored by TLC. The solvents were evaporated in vacuo. The TFA salt of the initiator $(177.9 \mathrm{mg}$, $0.12 \mathrm{mmol}$ ) was obtained in quantitative yields and dried under vacuum.

${ }^{1} \mathrm{H}$ NMR $\left(400 \mathrm{MHz}, \mathrm{D}_{2} \mathrm{O}\right) \delta[\mathrm{ppm}]=1.38-1.46(\mathrm{~m}, 6 \mathrm{H}$, $\left.-\mathrm{CHCH}_{2} \mathrm{CH}_{2} \mathrm{CH}_{2}-\right)$, 1.56-1.73(m, $18 \mathrm{H},-\mathrm{NHCH}_{2} \mathrm{CH}_{2} \mathrm{CH}_{2} \mathrm{CH}_{2} \mathrm{NH}-$, 
$\left.-\mathrm{CH}_{2} \mathrm{CH}_{2} \mathrm{CH}_{2} \mathrm{NH}_{2}\right), 1.84-1.93\left(\mathrm{~m}, 6 \mathrm{H},-\mathrm{CHCH}_{2} \mathrm{CH}_{2}-\right), 2.93-3.01(\mathrm{~m}$ $\left.6 \mathrm{H},-\mathrm{CH}_{2} \mathrm{CH}_{2} \mathrm{NH}_{2}\right), 3.26-3.32\left(\mathrm{~m}, 6 \mathrm{H},-\mathrm{CH}_{2} \mathrm{CH}_{2} \mathrm{NHCOCH}-\right), 3.40$ $3.46\left(\mathrm{~m}, 6 \mathrm{H},-\mathrm{CH}_{2} \mathrm{CH}_{2} \mathrm{NH}-\right), 3.89-3.96\left(\mathrm{~m}, 3 \mathrm{H},-\mathrm{COCHNH}_{2}\right), 8.23(\mathrm{~s}$, $3 \mathrm{H},=\mathrm{CH})$

${ }^{13} \mathrm{C}$ NMR $\left(400 \mathrm{MHz}, \mathrm{D}_{2} \mathrm{O}\right) \delta[\mathrm{ppm}]=21.29\left(-\mathrm{CHCH}_{2} \mathrm{CH}_{2} \mathrm{CH}_{2}-\right), 25.72$ ( $\left.-\mathrm{NHCH}_{2} \mathrm{CH}_{2} \mathrm{CH}_{2} \mathrm{CH}_{2} \mathrm{NH}-\right), 25.82\left(-\mathrm{NHCH}_{2} \mathrm{CH}_{2} \mathrm{CH}_{2} \mathrm{CH}_{2} \mathrm{NH}-\right), 26.32$ $\left(-\mathrm{CH}_{2} \mathrm{CH}_{2} \mathrm{CH}_{2} \mathrm{NH}_{2}\right), 30.33\left(-\mathrm{CHCH}_{2} \mathrm{CH}_{2}-\right), 38.91 \quad\left(-\mathrm{CH}_{2} \mathrm{CH}_{2} \mathrm{NH}_{2}\right)$, $39.13\left(-\mathrm{CH}_{2} \mathrm{CH}_{2} \mathrm{NHCOCH}-\right), \quad 39.62\left(-\mathrm{CH}_{2} \mathrm{CH}_{2} \mathrm{NHCOC}=\mathrm{C}-\right), 53.08$ $(-\mathrm{COCHNH}-), 128.59(=\mathrm{CH}), 135.07(=\mathrm{C}=), 168.91\left(-\mathrm{NHCOCHNH}_{2}\right)$, $169.33(=\mathrm{CCONH}-)$.

Monomer Synthesis: Sarcosine-N-Carboxyanhydride: The synthesis of sarcosine NCA was adapted from literature and modified. ${ }^{[67]}$ Sarcosine ( $50.96 \mathrm{~g}, 572 \mathrm{mmol}, 1 \mathrm{eq}$ ) was weighed into a pre-dried three neck round bottomed flask and dried in vacuo for 1 h. $520 \mathrm{~mL}$ abs. THF were added under a steady flow of nitrogen and diphosgene $(55.2 \mathrm{~mL}, 457.6 \mathrm{mmol}$, $0.8 \mathrm{eq})$ was added slowly via syringe. The colorless suspension was heated to $70{ }^{\circ} \mathrm{C}$ yielding a clear solution after $3 \mathrm{~h}$ of stirring. A steady flow of dry nitrogen was led through the solution into two gas washing bottles filled with aqueous sodium hydroxide solution to remove excess $\mathrm{HCl}$ and phosgene. The solvent was evaporated under reduced pressure yielding a brownish oil as crude reaction product. The oil was heated to $50{ }^{\circ} \mathrm{C}$ and dried under reduced pressure $\left(20 \mathrm{mbar}\right.$, then $<10^{-1} \mathrm{mbar}$ for $2 \mathrm{~h}$ ) to obtain an amorphous solid. The crude reaction product was redissolved in $60 \mathrm{~mL} \mathrm{THF}$ and precipitated with $300 \mathrm{~mL}$ dry $n$-hexane. The solution was cooled to $-18{ }^{\circ} \mathrm{C}$ to complete precipitation and was filtered off under dry nitrogen atmosphere. Afterward, a stream of dry nitrogen was used to dry the product for $60-90 \mathrm{~min}$ to remove residual traces of THF. The next day, the product was dried in high vacuum for $2 \mathrm{~h}$ in the sublimation apparatus. Then, the crude product was sublimated at $80-85{ }^{\circ} \mathrm{C}$ and $<1 \times 10^{-2}$ mbar. The product was collected from the sublimation apparatus in a glove box on the same day and subsequently aliquoted when the melting point was above $100{ }^{\circ} \mathrm{C}$. Colorless crystals were obtained $(64 \%) \cdot \mathrm{mp}=103^{\circ} \mathrm{C}$,

${ }^{1} \mathrm{H}$ NMR $\left(300 \mathrm{MHz}, \mathrm{CDCl}_{3}\right) \delta[\mathrm{ppm}]=2.86\left(\mathrm{~s}, 3 \mathrm{H},-\mathrm{NHCH}_{3}\right), 4.22$ (s, $2 \mathrm{H},-\mathrm{NHCH}_{2} \mathrm{CO}-$ ).

$N$ - $\varepsilon$-Tert-Butyloxycarbonyl-L-Lysine $\quad N$-Carboxyanhydride: $\quad N$ - $\varepsilon$-Bocprotected lysine $(9.8 \mathrm{~g}, 39.8 \mathrm{mmol})$ were weighed into a three-neck flask and dried under vacuum for $1 \mathrm{~h}$. The solid was suspended in $300 \mathrm{~mL}$ of absolute THF under a steady flow of dry nitrogen. Afterward, abs. trimethylsilylchloride $(9.9 \mathrm{~mL}, 79.6 \mathrm{mmol})$ and abs. triethylamine (TEA, $11.0 \mathrm{~mL}, 79.6 \mathrm{mmol}$ ) were added slowly via syringe. The suspension was stirred for $2 \mathrm{~h}$ followed by the addition of diphosgene $(4.8 \mathrm{~mL}$, $39.8 \mathrm{mmol}$ ), again via syringe. The suspension was mildly refluxed for another $2 \mathrm{~h}$. Overnight, a steady flow of dry nitrogen was led through the solution into two gas washing bottles filled with aqueous $\mathrm{NaOH}$ solution removing excess phosgene. The suspension was filtered under dry nitrogen atmosphere to remove the salts of TEA and unconverted amino acid. The filtrate was evaporated under reduced pressure. Subsequently, abs. THF was added to completely dissolve the crude reaction product. The solution was precipitated with absolute $n$-hexane and stored at $4{ }^{\circ} \mathrm{C}$ for $1 \mathrm{~h}$. The solid was collected by filtration under dry nitrogen atmosphere and washed with $n$-hexane. The crude reaction product was then recrystallized twice with absolute $\mathrm{THF} / n$-hexane. $6.52 \mathrm{~g}$ of purified reaction product $(23.9 \mathrm{mmol}$; $68 \%$ yield; colorless needles) were transferred into a Schlenk tube and stored at $-80^{\circ} \mathrm{C} . \mathrm{mp}=$ $138.3^{\circ} \mathrm{C}$ (Lit. $134-137^{\circ} \mathrm{C}$ ).

${ }^{1} \mathrm{H}$ NMR $\left(400 \mathrm{MHz}\right.$, DMSO- $\left.\mathrm{D}_{6}\right): \delta[\mathrm{ppm}]=1.45-1.12(\mathrm{~m}, 13 \mathrm{H}$, $-\mathrm{CHCH}_{2} \mathrm{CH}_{2} \mathrm{CH}_{2} \mathrm{CH}_{2} \mathrm{NH}-$ and $\left.-\mathrm{NHCOOC}\left(\mathrm{CH}_{3}\right)_{3}\right)$, $1.79-1.56$ $\left(\mathrm{m}, 2 \mathrm{H},-\mathrm{CHCH}_{2} \mathrm{CH}_{2} \mathrm{CH}_{2} \mathrm{CH}_{2} \mathrm{NH}-\right), 2.90\left(\mathrm{q},{ }^{3}\right) \mathrm{H}, \mathrm{H}=6.03 \mathrm{~Hz}, 2 \mathrm{H}$, $\left.\left.-\mathrm{CH}_{2} \mathrm{NHBoc}\right), 4.42\left(\mathrm{t},{ }^{3}\right) \mathrm{H}, \mathrm{H}, 1 \mathrm{H},=6.35 \mathrm{~Hz},-\mathrm{COCHCH}_{2}-\right), 6.95-6.34$ (br, 1H, -NHBoc), 9.07 (s, 1H, -NHCOOCO).

Polymer Synthesis: 3-Arm Poly (N-E-Tert-Butyloxycarbonyl-L-Lysine) Stars, $\left(p L y s(B o c)_{n}\right)_{3}$ : All polymerizations for different chain lengths were carried out in the same way with both kind of 3-arm initiator. In the following, a typical experiment for the synthesis of Butyl (pLys (Boc) $\left.)_{10}\right)_{3}$ is described.

Lys(Boc)-NCA (260.5 mg, $0.96 \mathrm{mmol}, 1 \mathrm{eq})$ were transferred under nitrogen counter flow into a pre-dried Schlenk-tube, equipped with a stir-bar and again dried in high vacuum for $30 \mathrm{~min}$. Then, the NCA was dissolved in $2 \mathrm{~mL}$ of abs. DMF. At the same time, TFA salt of $N^{1}, N^{3}, N^{5}$-Tris(2-(2-aminobutyl))benzene (24.4 mg, $32 \mu \mathrm{mol}, 1 / 30$ eq) were weighed into a pre-dried Schlenk-tube and again dried in high vacuum. After dissolving the initiator in $0.5 \mathrm{~mL}$ DMF, freshly distilled DIPEA (17.96 $\mu \mathrm{L}, 105.6 \mu \mathrm{mol}, 3.3 / 30 \mathrm{eq})$ was added and transferred completely to the monomer solution via syringe. The solution was stirred at $0{ }^{\circ} \mathrm{C}$ and kept at a constant pressure of 1.25 bar of dry nitrogen via the Schlenk-line to prevent impurities from entering the reaction vessel while allowing $\mathrm{CO}_{2}$ to escape. Completion of the reaction was confirmed by IR spectroscopy (disappearance of the NCA peaks [1853 and $\left.1786 \mathrm{~cm}^{-1}\right]$ ). Directly after completion of the reaction, the polymer was precipitated in diethyl ether and centrifuged $\left(4500 \mathrm{rpm}\right.$ at $4{ }^{\circ} \mathrm{C}$ for $15 \mathrm{~min}$ ). After discarding the liquid fraction, fresh diethyl ether was added, and the polymer was re-suspended using sonication. The suspension was centrifuged again, and the procedure was repeated. The polymer was then dissolved in methanol and lyophilized by the addition of $\mathrm{H}_{2} \mathrm{O}$ to obtain a fluffy powder (197 mg, 81\%). For different initiators and chain lengths, yields ranged from $81 \%$ to $89 \%$.

${ }^{1} \mathrm{H}$ NMR $\left(400 \mathrm{MHz}\right.$, DMSO- $\left.\mathrm{d}_{6}\right): \delta[\mathrm{ppm}]=1.20-1.90(\mathrm{br}, 15 \mathrm{nH}$, $-\mathrm{CHCH}_{2} \mathrm{CH}_{2} \mathrm{CH}_{2} \mathrm{CH}_{2} \mathrm{NH}$ and $\left.-\mathrm{C}\left(\mathrm{CH}_{3}\right)_{3}\right), 2.87$ (s, br, $\left.2 \mathrm{nH},-\mathrm{CH}_{2} \mathrm{NHBoc}\right)$, 3.62-4.31 (br, nH, -COCHNH), 6.30-6.74 (br, nH, - NHCOOC $\left.\left(\mathrm{CH}_{3}\right)_{3}\right)$, 7.70-8.23 (br, $\mathrm{nH},-\mathrm{COCHNH}-), \quad 8.38\left(\mathrm{~s}, 3 \mathrm{H},=\mathrm{CH}_{(\text {ini) }}\right), \quad 8.69$ (s, $\left.3 \mathrm{H},=\mathrm{CCONH}_{(\text {ini) }}\right)^{-}$.

For cystamine-based 3-arm initiator:

${ }^{1} \mathrm{H}$ NMR $\left(400 \mathrm{MHz}, \mathrm{DMSO}-\mathrm{d}_{6}\right): \delta[\mathrm{ppm}]=1.20-1.90(\mathrm{br}, 15 \mathrm{nH}$, $-\mathrm{CHCH}_{2} \mathrm{CH}_{2} \mathrm{CH}_{2} \mathrm{CH}_{2} \mathrm{NH}$ and $\left.-\mathrm{C}\left(\mathrm{CH}_{3}\right)_{3}\right), 2.87$ (s, br, $\left.2 \mathrm{nH},-\mathrm{CH}_{2} \mathrm{NHBoc}\right)$, 3.62-4.31 (br, nH, $-\mathrm{COCHNH}), 6.30-6.74\left(\mathrm{br}, \mathrm{nH},-\mathrm{NHCOOC}\left(\mathrm{CH}_{3}\right)_{3}\right)$, 7.70-8.23 (br, $\mathrm{nH},-\mathrm{COCHNH-)}, 8.43\left(\mathrm{~s}, 3 \mathrm{H},=\mathrm{CH}_{(\text {ini) }}\right), 8.91$ (s, $3 \mathrm{H},=\mathrm{CCONH}_{\text {(ini) }}-$ ).

6-Arm Poly (N-E-Tert-Butyloxycarbonyl-L-Lysine) Stars, $\left(p L y s(B o c)_{n}\right)_{6}$ : All polymerizations for different chain lengths were carried out in the same way with both kind of 6 -arm initiator. In the following, a typical experiment for the synthesis of Butyl(pLys (Boc) $\left.)_{10}\right)_{6}$ is described.

Lys(Boc)-NCA (407 mg, $1.49 \mathrm{mmol}, 1 \mathrm{eq}$ ) were transferred under nitrogen counter flow into a pre-dried Schlenk-tube, equipped with a stir-bar and again dried in high vacuum for $30 \mathrm{~min}$. Then, the NCA was dissolved in $3.5 \mathrm{~mL}$ of dry DMF. At the same time, TFA salt of butylbased 6 -arm initiator (37 mg, $24.8 \mu \mathrm{mol}, 1 / 60 \mathrm{eq}$ ) were weighed into a pre-dried Schlenk-tube and again dried in high vacuum. After dissolving the initiator in $0.5 \mathrm{~mL}$ abs. DMF, freshly distilled DIPEA $(27.84 \mu \mathrm{L}$, $163.68 \mu \mathrm{mol}, 6.6 / 60 \mathrm{eq})$ was added and transferred completely to the monomer solution via syringe. The solution was stirred at $0{ }^{\circ} \mathrm{C}$ and kept at a constant pressure of 1.25 bar of dry nitrogen via the Schlenk-line to prevent impurities from entering the reaction vessel while allowing $\mathrm{CO}_{2}$ to escape. Completion of the reaction was confirmed by IR spectroscopy (disappearance of the NCA peaks [1853 and $\left.1786 \mathrm{~cm}^{-1}\right]$ ). Directly after completion of the reaction, the polymer was precipitated in diethyl ether and centrifuged $\left(4500 \mathrm{rpm}\right.$ at $4{ }^{\circ} \mathrm{C}$ for $15 \mathrm{~min}$ ). After discarding the liquid fraction, new diethyl ether was added, and the polymer was re-suspended using sonication. The suspension was centrifuged again, and the procedure was repeated. The polymer was then dissolved in methanol and lyophilized by the addition of $\mathrm{H}_{2} \mathrm{O}$ to obtain a fluffy powder ( $370.6 \mathrm{mg}, 98 \%$ ). For different initiators, yields ranged from $98 \%$ to $91 \%$.

${ }^{1} \mathrm{H}$ NMR $\left(400 \mathrm{MHz}, \mathrm{DMSO}-\mathrm{d}_{6}\right): \delta[\mathrm{ppm}]=1.20-1.90(\mathrm{br}, 15 \mathrm{nH}$, $-\mathrm{CHCH}_{2} \mathrm{CH}_{2} \mathrm{CH}_{2} \mathrm{CH}_{2} \mathrm{NH}$ and $\left.-\mathrm{C}\left(\mathrm{CH}_{3}\right)_{3}\right), 2.87$ (s, br, $\left.2 \mathrm{nH},-\mathrm{CH}_{2} \mathrm{NHBoc}\right)$, 3.62-4.31 (br, nH, -COCHNH), 6.30-6.74 (br, nH, $\left.-\mathrm{NHCOOC}\left(\mathrm{CH}_{3}\right)_{3}\right)$, 7.70-8.23 (br, nH,-COCHNH-), $8.38\left(\mathrm{~s}, 3 \mathrm{H},=\mathrm{CH}_{(\text {ini) }}\right), 8.68$ (s, $\left.3 \mathrm{H},=\mathrm{CCONH}_{\text {(ini) }}-\right)$.

For cystamine-based 6-arm initiator:

${ }^{1} \mathrm{H}$ NMR $\left(400 \mathrm{MHz}\right.$, DMSO- $\left.\mathrm{d}_{6}\right): \delta[\mathrm{ppm}]=1.20-1.90(\mathrm{br}, 15 \mathrm{nH}$, $-\mathrm{CHCH}_{2} \mathrm{CH}_{2} \mathrm{CH}_{2} \mathrm{CH}_{2} \mathrm{NH}$ and $\left.-\mathrm{C}\left(\mathrm{CH}_{3}\right)_{3}\right), 2.87$ (s, br, $\left.2 \mathrm{nH},-\mathrm{CH}_{2} \mathrm{NHBoc}\right)$, 3.62-4.31 (br, nH, -COCHNH), 6.30-6.74 (br, nH, - NHCOOC $\left.\left(\mathrm{CH}_{3}\right)_{3}\right)$, 7.70-8.23 (br, nH, -COCHNH-), $8.44\left(\mathrm{~s}, 3 \mathrm{H},=\mathrm{CH}_{(\text {ini) }}\right), 8.93(\mathrm{~s}, 3 \mathrm{H}$, $\left.=\mathrm{CCONH}_{(\mathrm{ini})}-\right)$.

3-Arm Poly (N-E-Tert-Butyloxycarbonyl-L-Lysine)-Polysarcosine Stars,

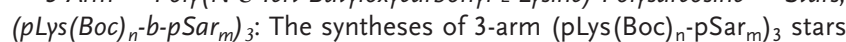
were carried out in the similar way as for $\left(\operatorname{pLys}(\operatorname{Boc})_{n}\right)_{3}$ stars, using those as macroinitiator. 
In a typical experiment, Butyl(pLys(Boc) $\left.{ }_{10}\right)_{3}(102.2 \mathrm{mg}, 13.4 \mu \mathrm{mol}$, $1 / 300$ eq) as macroinitiator was weighed into a flame-dried Schlenkflask and dried in high vacuum for $30 \mathrm{~min}$. The macroinitiator was dissolved in $1 \mathrm{~mL}$ of abs. DMF and freshly distilled DIPEA $(7.5 \mu \mathrm{L}$, $44.2 \mu \mathrm{mol}, 3,3 / 300 \mathrm{eq})$ was directly added. The mixture was stirred over night at room temperature. The next day, SarNCA $(458.6 \mathrm{mg}$, $4.02 \mathrm{mmol}, 1 \mathrm{eq})$ was weighed into a flame-dried Schlenk-flask and dried in high vacuum for $30 \mathrm{~min}$. Then, the NCA were dissolved in $3.5 \mathrm{~mL}$ of abs. DMF. The initiator solution was added to the monomer solution via syringe. The reaction mixture was stirred at $0{ }^{\circ} \mathrm{C}$ and kept at a constant pressure of 0.25 bar of dry nitrogen via the Schlenk-line. After the completion of the reaction, which was confirmed by IR spectroscopy, the polymer was precipitated in diethyl ether and centrifuged (4500 rpm at $4{ }^{\circ} \mathrm{C}$ for $15 \mathrm{~min}$ ). After discarding the liquid fraction, fresh diethyl ether was added, and the polymer was re-suspended. The suspension was centrifuged again, and the procedure was repeated. The polymer was then dissolved in methanol, dialyzed, and afterward lyophilized to obtain $224 \mathrm{mg}(58 \%)$ of a fluffy powder. For different polypeptide-star macroinitiators, yields ranged from $55 \%$ to $61 \%$.

${ }^{1} \mathrm{H}$ NMR $\left(400 \mathrm{MHz}\right.$, DMSO- $\left.\mathrm{d}_{6}\right): \delta[\mathrm{ppm}]=1.10-2.20(\mathrm{br}, 15 \mathrm{nH}$, $-\mathrm{CHCH}_{2} \mathrm{CH}_{2} \mathrm{CH}_{2} \mathrm{CH}_{2} \mathrm{NH}$ and $\left.-\mathrm{C}\left(\mathrm{CH}_{3}\right)_{3}\right), 2.72-2.93$ (br, $2 \mathrm{nH}+3 \mathrm{mH}$, $-\mathrm{CH}_{2} \mathrm{NHCOOC}-$ and $\left.-\mathrm{NHCH}_{3}-\right), 3.77-4.34$ (br, $\mathrm{nH}+2 \mathrm{mH}$, $-\mathrm{COCHNH}-$ and $-\mathrm{COCH}_{2} \mathrm{NCH}_{3}-$ ), 6.33-6.71 (br, $\left.\mathrm{nH},-\mathrm{NHBoc}\right)$, 7.72-8.26 (br, $\mathrm{nH},-\mathrm{COCHNH}-), 8.38$ (s, $\left.3 \mathrm{H},=\mathrm{CH}_{(\text {ini) }}\right), 8.69$ (s, $3 \mathrm{H},=\mathrm{CCONH}_{\text {(ini) }}-$ ).

For cystamine-based 3-arm initiator:

${ }^{1} \mathrm{H}$ NMR $\left(400 \mathrm{MHz}\right.$, DMSO- $\left.\mathrm{d}_{6}\right): \delta[\mathrm{ppm}]=1.10-2.20(\mathrm{br}, 15 \mathrm{nH}$, $-\mathrm{CHCH}_{2} \mathrm{CH}_{2} \mathrm{CH}_{2} \mathrm{CH}_{2} \mathrm{NH}$ and $\left.-\mathrm{C}\left(\mathrm{CH}_{3}\right)_{3}\right), 2.72-2.93$ (br, $2 \mathrm{nH}+3 \mathrm{mH}$, $-\mathrm{CH}_{2} \mathrm{NHCOOC}-$ and $-\mathrm{NHCH}_{3}-$ ), 3.77-4.34 (br, nH+2mH, $-\mathrm{COCHNH}-$ and $-\mathrm{COCH}_{2} \mathrm{NCH}_{3}-$ ), 6.33-6.71 (br, $\left.\mathrm{nH},-\mathrm{NHBoc}\right), 7.72-8.26(\mathrm{br}, \mathrm{nH}$, $-\mathrm{COCHNH}), 8.43\left(\mathrm{~s}, 3 \mathrm{H},=\mathrm{CH}_{(\text {ini) }}\right), 8.93\left(\mathrm{~s}, 3 \mathrm{H},=\mathrm{CCONH}_{(\text {ini) }}-\right)$.

6-Arm Poly (N-E-Tert-Butyloxycarbonyl-L-Lysine)-Polysarcosine Stars, $\left(p L y s(B o c)_{n}-b-p S a r_{100}\right)_{6}$ : The syntheses of 6-arm (pLys $\left.\left(B_{0}\right)_{n}-p S a r_{100}\right)_{6}$ stars were carried out in the similar way as for $\left(p L y s(B \circ)_{n}\right)_{6}$ stars, using those as macroinitiator.

In a typical experiment, butyl(pLys(Boc) 10$)_{6}(45 \mathrm{mg}, 2.96 \mu \mathrm{mol}$, $1 / 600$ eq) as macroinitiator was weighed into a flame-dried Schlenkflask and dried in high vacuum for $30 \mathrm{~min}$. The macroinitiator was dissolved in $0.5 \mathrm{~mL}$ of abs. DMF and freshly distilled DIPEA $(3.32 \mu \mathrm{L}$, $19.54 \mu \mathrm{mol}, 6,6 / 600 \mathrm{eq})$ was directly added. The mixture was stirred overnight at room temperature. The next day, SarNCA $(204.9$ mg, $1.78 \mathrm{mmol}, 1 \mathrm{eq}$ ) was weighed into a flame-dried Schlenk-flask and dried in high vacuum for $30 \mathrm{~min}$. Then, the NCA were dissolved in $1.5 \mathrm{~mL}$ of abs. DMF. The initiator solution was added to the monomer solution via syringe. The reaction mixture was stirred at $0{ }^{\circ} \mathrm{C}$ and kept at a constant pressure of 0.25 bar of dry nitrogen via the Schlenk-line. After completion of the reaction, which was confirmed by IR spectroscopy, the polymer was precipitated in diethyl ether and centrifuged $(4500 \mathrm{rpm}$ at $4{ }^{\circ} \mathrm{C}$ for $15 \mathrm{~min}$ ). After discarding the liquid fraction, fresh diethyl ether was added, and the polymer was re-suspended. The suspension was centrifuged again, and the procedure was repeated. The polymer was then dissolved in methanol, dialyzed, and afterward lyophilized to obtain $105 \mathrm{mg}(61 \%)$ of a fluffy powder. For different polypeptide-star macroinitiators, yields ranged from $58 \%$ to $65 \%$.

${ }^{1} \mathrm{H}$ NMR $\left(400 \mathrm{MHz}, \mathrm{DMSO}-\mathrm{d}_{6}\right): \delta[\mathrm{ppm}]=1.10-2.20(\mathrm{br}, 15 \mathrm{nH}$, $-\mathrm{CHCH}_{2} \mathrm{CH}_{2} \mathrm{CH}_{2} \mathrm{CH}_{2} \mathrm{NH}$ and $\left.-\mathrm{C}\left(\mathrm{CH}_{3}\right)_{3}\right), 2.72-2.93(\mathrm{br}, 2 \mathrm{nH}+3 \mathrm{mH}$, $-\mathrm{CH}_{2} \mathrm{NHCOOC}-$ and $\left.-\mathrm{NHCH}_{3}-\right), 3.77-4.34$ (br, $\mathrm{nH}+2 \mathrm{mH}$, $-\mathrm{COCHNH}-$ and $\left.-\mathrm{COCH}_{2} \mathrm{NCH}_{3}-\right)$, 6.33-6.71 (br, $\left.\mathrm{nH},-\mathrm{NHBoc}\right)$, $7.72-8.26(\mathrm{br}, \mathrm{nH},-\mathrm{COCHNH}-), 8.38\left(\mathrm{~s}, 3 \mathrm{H},=\mathrm{CH}_{(\text {ini) }}\right), 8.69$ (s, $3 \mathrm{H},=\mathrm{CCONH}_{(\text {ini) }}-$ ).

For cystamine-based 6-arm initiator:

${ }^{1} \mathrm{H}$ NMR $\left(400 \mathrm{MHz}, \mathrm{DMSO}-\mathrm{d}_{6}\right): \delta[\mathrm{ppm}]=1.10-2.20(\mathrm{br}, 15 \mathrm{nH}$, $-\mathrm{CHCH}_{2} \mathrm{CH}_{2} \mathrm{CH}_{2} \mathrm{CH}_{2} \mathrm{NH}-$ and $\left.-\mathrm{C}\left(\mathrm{CH}_{3}\right)_{3}\right), 2.72-2.93(\mathrm{br}, 2 \mathrm{nH}+3 \mathrm{mH}$, $-\mathrm{CH}_{2} \mathrm{NHCOOC}-$ and $\left.-\mathrm{NHCH}_{3}-\right), 3.77-4.34$ (br, $\mathrm{nH}+2 \mathrm{mH}$, $-\mathrm{COCHNH}-$ and $\left.-\mathrm{COCH}_{2} \mathrm{NCH}_{3}-\right), 6.33-6.71$ (br, $\mathrm{nH},-\mathrm{NHBoc}$ ), $7.72-8.26$ (br, $\mathrm{nH},-\mathrm{COCHNH}-), 8.43\left(\mathrm{~s}, 3 \mathrm{H},=\mathrm{CH}_{(\mathrm{ini})}\right), 8.93$ (s, $3 \mathrm{H},=\mathrm{CCONH}_{\text {(ini) }}-$ ).
End Group Modification: N-Acetyl Star Polymers, $\left(p L y s(B o c)_{n}{ }^{-b}\right.$ $\left.p \mathrm{Sar}_{m}-A c\right)_{3 \text { or }}$ : All acetylations of polypept(o)ide stars were carried out in the same way.

In a typical experiment, SS(pLys(Boc) 10-pSar $\left._{100}\right)_{6}(60 \mathrm{mg}, 1.0 \mu \mathrm{mol}$, $1 \mathrm{eq)}$ was weighed into a flame-dried Schlenk-flask and dried under vacuum for $30 \mathrm{~min}$. The polymer was dissolved in $0.5 \mathrm{~mL}$ abs. DMF and TEA (2.8 $\mu \mathrm{L}, 20.0 \mu \mathrm{mol}, 20 \mathrm{eq})$ was added directly with a pipette under nitrogen counter flow. The mixture was stirred at RT for 30 min to activate the $\mathrm{N}$-termini of the star polymer. Then, acetic anhydride (945 $\mu \mathrm{L}, 10.0 \mu \mathrm{mol}, 10$ eq) was added to the mixture and left to react at RT for $24 \mathrm{~h}$. For purification, the polymer was precipitated in diethyl ether and centrifuged $\left(4500 \mathrm{rpm}\right.$ at $4{ }^{\circ} \mathrm{C}$ for $\left.15 \mathrm{~min}\right)$. The procedure was repeated two times. $56.5 \mathrm{mg}(98 \%)$ of a colorless fluffy powder was obtained. For different star polymers and initiators, yields ranged from $92 \%$ to $98 \%$.

Core Modifications of Polypept(o)ide Stars: Deprotection of ( $p L y s(B o c)_{n^{-}}$ $\left.b-p \mathrm{Sar}_{m}-\mathrm{Ac}\right)_{3 \text { or } 6}$ : All deprotections of different polypept(o)ide stars have been performed in the same way. In the following, a typical deprotection for SS(pLys (Boc) $\left.{ }_{20}-\mathrm{pSar}_{100}-\mathrm{Ac}\right)_{6}$ is described.

$\mathrm{SS}\left(\mathrm{pLys}(\mathrm{Boc})_{20} \mathrm{pSar}_{100}-\mathrm{Ac}\right)_{6}(41 \mathrm{mg}, 0.6 \mu \mathrm{mol}, 1 \mathrm{eq})$ was dissolved in $500 \mu \mathrm{L} \mathrm{H} \mathrm{H}_{2} \mathrm{O}$. During cooling in an ice bath, $250 \mu \mathrm{L}$ TFA was added to the polymer solution. After stirring at RT for $2 \mathrm{~h}$, the polymer solution was consequently dialyzed against aqueous sodium hydrogen carbonate solution for 1 day and $\mathrm{H}_{2} \mathrm{O}$ for additional 2 days while solvent exchange was frequently conducted. After lyophilization, SS (pLys $\left.20-\mathrm{pSar}_{100}-\mathrm{Ac}\right)_{6}$ was obtained in quantitative yields as a colorless powder.

' $\mathrm{H}$ NMR $\left(400 \mathrm{MHz}, \mathrm{D}_{2} \mathrm{O}\right): \delta[\mathrm{ppm}]=1.19-1.84(\mathrm{br}, 6 \mathrm{nH}$, $-\mathrm{CHCH}_{2} \mathrm{CH}_{2} \mathrm{CH}_{2} \mathrm{CH}_{2} \mathrm{NH}_{2}$ ), 2.72-3.03 (br, $2 \mathrm{nH}+3 \mathrm{mH},-\mathrm{CH}_{2} \mathrm{NH}_{2}$ and $\left.-\mathrm{NHCH}_{3}\right), 3.97-4.53\left(\mathrm{br}, \mathrm{nH}+2 \mathrm{mH},-\mathrm{COCHNH}-\right.$ and $-\mathrm{COCH}_{2} \mathrm{NCH}_{3}-$ ). $8.34\left(\mathrm{~s}, 3 \mathrm{H},=\mathrm{CH}_{\text {(ini) }}\right)$.

Initiator signal for butyl-based 6-arm star polymers: 8.33

For 3-arm star polymers:

'H NMR (400 MHz, $\left.\mathrm{D}_{2} \mathrm{O}\right): \delta[\mathrm{ppm}]=1.19-1.84(\mathrm{br}, 6 \mathrm{nH}$, $-\mathrm{CHCH}_{2} \mathrm{CH}_{2} \mathrm{CH}_{2} \mathrm{CH}_{2} \mathrm{NH}_{2}$ ), 2.72-3.03 (br, $2 \mathrm{nH}+3 \mathrm{mH},-\mathrm{CH}_{2} \mathrm{NH}_{2}$ and $\left.-\mathrm{NHCH}_{3}\right), 3.97-4.53\left(\mathrm{br}, \mathrm{nH}+2 \mathrm{mH},-\mathrm{COCHNH}-\right.$ and $-\mathrm{COCH}_{2} \mathrm{NCH}_{3}-$ ). Initiator signal $\left(\mathrm{s}, 3 \mathrm{H},=\mathrm{CH}_{(\text {ini) }}\right)$ for cystamine-based 3-arm stars: 8.27 and for butyl-based 3-arm stars: 8.23

Core Labeling of ( $p$ L $p s-b$-pSar) Stars with Alexa Fluor 647: In a typical experiment, Butyl( $\mathrm{pLys}_{25}-b$-pSar $\left.{ }_{100}\right)_{3}(13.5 \mathrm{mg}, 0.3 \mu \mathrm{mol}, 1$ eq) were dissolved in $0.5 \mathrm{~mL}$ of abs. DMF under dry nitrogen atmosphere and freshly distilled DIPEA ( $0.5 \mu \mathrm{L}, 3 \mu \mathrm{mol}, 10 \mathrm{eq})$ was added. 2 eq $(0.6 \mu \mathrm{mol})$ of Alexa Fluor 647 NHS ester dissolved in abs. DMF were added via syringe. The solution was protected from light and stirred for 3 days at RT. After that, the labeled polymer was directly dialyzed against methanol and purified by Amicon Ultra Centrifugal Filters (10K) with a mixture of $\mathrm{H}_{2} \mathrm{O}$ and methanol (1:1) to remove unbound dye. Lyophilization yielded $12 \mathrm{mg}$ (yield: 86\%) of labeled polymer as fluffy, blue solid.

Modification with $N, N^{\prime}$-diBoc-L-Histidine: All functionalizations of 3-arm and 6-arm ( $\left.\mathrm{pLys}_{\mathrm{n}}-\mathrm{pSar}_{\mathrm{m}}-\mathrm{Ac}\right)_{3}$ or 6 star polymers with varied amount of (Boc)-L-His(Boc)-OH were performed in the same way. In the following, the synthesis of $\mathrm{SS}\left(\mathrm{pLys}_{21} / \mathrm{pLys}(\mathrm{Boc}) \mathrm{His}(\mathrm{Boc})_{4}-\mathrm{pSar}_{100}-\mathrm{Ac}\right)_{3}$ is described.

$\mathrm{SS}\left(\mathrm{pLys}_{25}-\mathrm{pSar}_{100}-\mathrm{Ac}\right)_{3}(18.5 \mathrm{mg}, 0.45 \mu \mathrm{mol}, 1 \mathrm{eq})$ was weighed into a Schlenk-flask, dissolved in $0.5 \mathrm{~mL}$ abs. DMF and freshly distilled DIPEA (1.2 $\mu \mathrm{L}, 6.75 \mu \mathrm{mol}, 15 \mathrm{eq}$ ) was added. In parallel, (Boc)-L-His(Boc)OH*benzene $(2.9 \mathrm{mg}, 6.75 \mu \mathrm{mol}, 15$ eq with respect to desired modified lysine units) was weighed into another Schlenk-flask and 1-ethyl-3-(3dimethylaminopropyl)carbodiimide $* \mathrm{HCl}(\mathrm{EDC} * \mathrm{HCl})(1.73 \mathrm{mg}, 9 \mu \mathrm{mol}$, 20 eq) as well as HOBt $(1.22 \mathrm{mg}, 9 \mu \mathrm{mol}, 20$ eq) was added. After dissolving in $0.5 \mathrm{~mL}$ abs. DMF, the solution was stirred for $30 \mathrm{~min}$ at RT in the presence of freshly distilled DIPEA $(1.9 \mu \mathrm{L}, 11.25 \mu \mathrm{mol}, 25 \mathrm{eq})$. The polymer and histidine solutions were combined and stirred for additional 3 days at RT, protected from light. The slightly yellow solution was subsequently dialyzed with a Spectra/Por (Roth) membrane with a nominal molecular weight cut-off (NMWCO) of $3500 \mathrm{~g} \mathrm{~mol}^{-1}$ against a mixture of $\mathrm{MeOH} / \mathrm{H}_{2} \mathrm{O}$ (50:50) for 3 days while solvent exchange was frequently conducted. After lyophilization, $17.22 \mathrm{mg}(85 \%)$ of the product was obtained as a colorless powder. 
${ }^{1} \mathrm{H}$ NMR $\left(400 \mathrm{MHz}\right.$, DMSO- $\left.\mathrm{d}_{6}\right): \delta[\mathrm{ppm}]=1.23-1.86(\mathrm{br}$, $6 \mathrm{nH}+18 \mathrm{rH},-\mathrm{CHCH}_{2} \mathrm{CH}_{2} \mathrm{CH}_{2} \mathrm{CH}_{2} \mathrm{NH}$ and $\left.2 x-\mathrm{NCOOC}\left(\mathrm{CH}_{3}\right)_{3}\right)$, 2.72$2.93\left(\mathrm{br}, 2 \mathrm{nH}+3 \mathrm{mH},-\mathrm{CH}_{2} \mathrm{NHCOOC}-\right.$ and $-\mathrm{NHCH}_{3}-$ ), 3.78-4.34 (br, $\mathrm{nH}+2 \mathrm{mH},-\mathrm{COCHNH}-$ and $\left.-\mathrm{COCH}_{2} \mathrm{NCH}_{3}-\right), 6.75(\mathrm{~s}, \mathrm{rH}$, $\left.-\mathrm{C}=\mathrm{CH}_{\mathrm{His}} \mathrm{NBoc}\right), 7.53\left(\mathrm{~s}, \mathrm{rH},-\mathrm{N}=\mathrm{CH}_{\mathrm{His}} \mathrm{NBoc}\right), 8.43\left(\mathrm{~s}, 3 \mathrm{H},=\mathrm{CH}_{(\text {ini) }}\right)$, $8.93\left(\mathrm{~s}, 3 \mathrm{H},=\mathrm{CCONH}_{(\text {ini) }}-\right)$.

The shiftings are the same for butyl-based 6-arm star polymers.

Deprotection of $N, N^{\prime}$-diBoc-L-Histidine Modified Polypept(o)ide Stars, $\left(p L y s_{n} / p L y s \mathrm{His}_{r}-p \mathrm{Sar}_{m}-A c\right)_{3}$ or 6 : For cleavage of Boc-groups, SS(pLys $\mathrm{s}_{21} /$ pLys $\left.\mathrm{His}_{4}-\mathrm{pSar}_{100}-\mathrm{Ac}\right)_{3}(15 \mathrm{mg})$ was dissolved in a mixture of $\mathrm{H}_{2} \mathrm{O}$ and TFA $(1 / 1)$ and the solution was stirred for $3 \mathrm{~h}$ at RT. The reaction mixture was subsequently dialyzed with a Spectra/Por (Roth) membrane with a nominal molecular weight cut-off (NMWCO) of $3500 \mathrm{~g} \mathrm{~mol}^{-1}$ against an aqueous solution of $\mathrm{NaHCO}_{3}$ for 1 day and afterward additional 3 days against $\mathrm{H}_{2} \mathrm{O}$. Lyophilization yielded the polymer in quantitative yields as a colorless powder.

${ }^{1} \mathrm{H}$ NMR $\left(400 \mathrm{MHz}, \mathrm{DMSO}-\mathrm{d}_{6}\right): \delta[\mathrm{ppm}]=1.23-1.66(\mathrm{br}, 6 \mathrm{nH}$, $-\mathrm{CHCH}_{2} \mathrm{CH}_{2} \mathrm{CH}_{2} \mathrm{CH}_{2} \mathrm{NH}-$ ), 2.72-2.95 (br, $2 \mathrm{nH}+3 \mathrm{mH},-\mathrm{CH}_{2} \mathrm{NHCOOC}-$ and $\left.-\mathrm{NHCH}_{3}-\right), \quad 3.89-4.34(\mathrm{br}, \mathrm{nH}+2 \mathrm{mH}, \quad-\mathrm{COCHNH}-$ and $\left.-\mathrm{COCH}_{2} \mathrm{NCH}_{3}-\right), \quad 6.87 \quad\left(\mathrm{~s}, \quad \mathrm{rH}, \quad-\mathrm{C}=\mathrm{CH}_{\mathrm{His}} \mathrm{NH}\right), \quad 7.62 \quad(\mathrm{~s}, \quad \mathrm{rH}$ $\left.-\mathrm{N}=\mathrm{CH}_{\mathrm{His}} \mathrm{NH}\right), 7.72-8.26(\mathrm{br}, \mathrm{nH},-\mathrm{CHNH}-), 8.44\left(\mathrm{~s}, 3 \mathrm{H},=\mathrm{CH}_{(\text {ini) }}\right)$, $8.93\left(\mathrm{~s}, 3 \mathrm{H},=\mathrm{CCONH}_{\text {(ini) }}-\right.$ ).

For butyl-based 6-arm star polymers:

${ }^{7} \mathrm{H}$ NMR $\left(400 \mathrm{MHz}, \mathrm{DMSO}-\mathrm{d}_{6}\right): \delta[\mathrm{ppm}]=1.23-1.66(\mathrm{br}, 6 \mathrm{nH}$, $-\mathrm{CHCH}_{2} \mathrm{CH}_{2} \mathrm{CH}_{2} \mathrm{CH}_{2} \mathrm{NH}-$ ), 2.72-2.95 (br, $2 \mathrm{nH}+3 \mathrm{mH},-\mathrm{CH}_{2} \mathrm{NHCOOC}-$ and $\left.-\mathrm{NHCH}_{3}-\right), \quad 3.89-4.34(\mathrm{br}, \quad \mathrm{nH}+2 \mathrm{mH},-\mathrm{COCHNH}-$ and $\left.-\mathrm{COCH}_{2} \mathrm{NCH}_{3}-\right), \quad 7.70 \quad\left(\mathrm{~s}, \quad \mathrm{rH}, \quad-\mathrm{C}=\mathrm{CH}_{\mathrm{His}} \mathrm{NH}\right), \quad 7.78 \quad(\mathrm{~s}, \quad \mathrm{rH}$, $\left.-\mathrm{N}=\mathrm{CH}_{\mathrm{His}} \mathrm{NH}\right), 7.72-8.26(\mathrm{br}, \mathrm{nH},-\mathrm{CHNH}-), 8.44\left(\mathrm{~s}, 3 \mathrm{H},=\mathrm{CH}_{(\text {ini) }}\right)$, $8.93\left(\mathrm{~s}, 3 \mathrm{H},=\mathrm{CCONH}_{\text {(ini) }}-\right)$.

DLS Measurements: The star polymer solution $\left(3 \mathrm{mg} \mathrm{mL}^{-1}\right.$ ) was transferred to a dust free flow box and all samples were filtered (Acrodisc GHP $0.2 \mu \mathrm{m}$ ) into dust free cylindrical scattering cells (Suprasil, $20 \mathrm{~mm}$ diameter, Hellma, Mühlheim, Germany). For data evaluation, experimental intensity correlation functions were transformed into amplitude correlation functions applying the Siegert relation extended to include negative values after baseline subtraction by calculation $\mathrm{g}_{1}(\mathrm{t})=$ $\operatorname{SIGN}\left(G_{2}(t)\right) \cdot \operatorname{SQRT}\left(\operatorname{ABS}\left(\left(G_{2}(t)-A\right) / A\right)\right.$. All field correlation functions usually showed monomodal decays and were fitted by a sum of two exponentials $g_{1}(t)=a \cdot \exp \left(-\frac{t}{b}\right)+c \cdot \exp (-t / d)$ to take polydispersity into account. Average apparent diffusion coefficients $D_{\text {app }}$ were calculated by applying $q_{2} \cdot D_{\text {app }}=\left(a \cdot b^{-1}+c \cdot d^{-1}\right) /(a+c)$ resulting in an angulardependent diffusion coefficient $D_{\text {app }}$ or reciprocal hydrodynamic radius $<1 / R_{h}>_{\text {app }}$, according to formal application of Stokes Einstein law. By extrapolation of $\left\langle 1 / R_{h}\right\rangle_{\text {app }}$ to $q=0$-average hydrodynamic radi $R_{h}=<1 / R_{h}>_{z}^{-1}$ were obtained (uncorrected for c-dependency). For single angle DLS at $173^{\circ}$, star polymer solutions $\left(1 \mathrm{mg} \mathrm{mL}^{-1}\right.$ in PBS, methanol, or HFIP) were measured in triplicates. For zeta potential measurements, star polymer solutions (1 $\mathrm{mg} \mathrm{mL}^{-1}$ ) in $10 \mathrm{~mm}$ aqueous $\mathrm{NaCl}$ were measured in triplicates.

Fluorescence Correlation Spectroscopy (FCS) Measurements: FCS measurements were performed using a commercial setup (Zeiss, Germany) consisting of the module ConfoCor 2 and an inverted microscope (Axiovert 200), equipped with a Zeiss C-Apochromat 40/1.2 W water immersion objective. For excitation of Alexa Fluor 647-labeled species, a $633 \mathrm{~nm} \mathrm{He} / \mathrm{Ne}$ (helium/neon) laser was used. The collected fluorescence was filtered through a LP650 long pass emission filter before reaching an avalanche photodiode detector that enables single-photon counting. All measurements were performed in eightwell polystyrene-chambered coverglass (Laboratory-Tek, Nalge Nunc International, Penfield, NY, USA) as a sample cell. For each sample, a series of ten measurements $(30 \mathrm{~s}$ each) was performed. The timedependent fluctuations of the fluorescence intensity $\delta I(t)$ caused by the diffusion of the fluorescent species through the confocal observation volume were recorded and analyzed by an autocorrelation function.

$G(\tau)=1+\frac{\delta l(t) \times \delta l(t+\tau)}{l(t)^{2}}$
As it has been shown theoretically for an ensemble of $m$ different types of freely diffusing fluorescent species, $G(\tau)$ has the analytical form of

$$
G(\tau)=1+\frac{1}{N} \sum_{i=1}^{m} \frac{f_{i}}{\left(1+\frac{\tau}{\tau_{D, i}}\right) \times \sqrt{1+\frac{\tau}{S^{2} \times \tau_{D, i}}}}
$$

Here, $N$ is the average number of diffusing fluorescent species in the observation volume, $\tau_{D, i}$ is the diffusion time of the $i$ th species, $f_{i}$ is the fraction of component $i$, and $S$ is the so-called structure parameter $S=\frac{z_{0}}{r_{0}}$, where $z_{0}$ and $r_{0}$ represent the axial and radial dimension of the confocal volume, respectively. Furthermore, the diffusion time $\tau_{D, i}$ is related to the respective diffusion coefficient $D_{i}$, through $D_{i}=\frac{r_{0}^{2}}{4 \times \tau_{D, i}}$. The experimental autocorrelation curve $G(\tau)$ was fitted yielding the corresponding diffusion time and subsequently, the diffusion coefficient of the fluorescent species. According to the Stokes-Einstein law, the hydrodynamic radii $R_{\mathrm{h}}$ can be calculated assuming spherical particles as $R_{\mathrm{h}}=\frac{k_{\mathrm{B}} \times T}{6 \times \pi \times \eta \times D}$, with $T$ as absolute temperature, $k_{B}$ as Boltzmann constant, and $\eta$ as viscosity of the solvent. Furthermore, FCS yielded also the fluorescent brightness $(F B)$ of the studied species defined as the ratio between the detected average fluorescent intensity and the mean number of fluorescent species in the observation volume, $F B=\frac{\langle l(t)\rangle}{N}$. As the value of $r_{0}$ depends on the characteristics of the specific optical setup, a calibration was performed prior to each measurement with Alexa Fluor 647 as reference standards with known diffusion coefficients. All fluorescent dye-labeled samples were dissolved and diluted in PBS $\left(\mathrm{pH} 7.4\right.$ ) to a concentration of $\mathrm{c} \approx 10^{-8}$ to $10^{-9} \mathrm{~mol} \mathrm{~L}^{-1}$.

Agarose Gel Electrophoresis: Agarose gels (0.75 w\%) were prepared by adding $1.2 \mathrm{~g}$ agarose to $160 \mathrm{~mL}$ Tris-borate-EDTA (TBE) buffer. The mixture was heated to dissolve the agarose, allowed to cool down, and $16 \mu \mathrm{L}$ GelRed for DNA staining were added. For complexation experiments, scrambled siRNA was used purchased from IBA GmbH (Göttingen, Germany). Heparin sodium salt from hog intestine was obtained from TCl Europe. Samples were prepared in PBS buffer at corresponding weight-to-weight ratios and incubated at RT for $30 \mathrm{~min}$. After the addition of loading buffer, the samples were loaded onto the gel in TBE buffer and an electric field (120 V for $30 \mathrm{~min}$ ) was applied. Visualization occurred in a dark hood under UV light (365 nm) and documentation was done by a DCC camera (Intas Scientific).

Degradation of Cationic Polypept(o)ide Stars with Protease: Polymer samples were first dissolved in the protease buffer, which was consisting of $0.01 \mathrm{M}$ sodium acetate, $0.005 \mathrm{~m}$ calcium acetate, and revealed a $\mathrm{pH}$ of 7. The protease solution with a concentration of $1 \mathrm{mg} \mathrm{mL}^{-1}$ was added to the polymers to achieve a polymer concentration of $10 \mathrm{mg} \mathrm{mL}^{-1}$ and the mixture was incubated at $20^{\circ} \mathrm{C}$ on a shaker. After day 4 and day 7 , samples were taken, directly lyophilized and subsequently analyzed by HFIP SEC.

Biological Evaluation: MTT Assay: The mouse neuroblastoma cells (Neuro2a/eGFPLuc) were cultured in DMEM low glucose medium (Sigma, Munich, Germany). Neuro2a/eGFPLuc cells were seeded into 96 -well plates at a density of 5.000 cells per well. After $24 \mathrm{~h}$, the medium was replaced with $80 \mu \mathrm{L}$ of fresh medium. Star polymers loaded with siRNA ( $\mathrm{w} / \mathrm{w}$ ratios 1:3, 1:5, 1:10, 1:20) were diluted into $20 \mu \mathrm{L}$ with HEPES buffered glucose (HBG) buffer, added to each well, and incubated at $37{ }^{\circ} \mathrm{C}$ for $48 \mathrm{~h}$. Afterward, MTT (3-(4,5-dimethylthiazol-2yl)-2,5-diphenyltetrazolium bromide) solution ( $10 \mu \mathrm{L}$ per well, $5.0 \mathrm{mg}$ $\mathrm{mL}^{-1}$ ) was added. After incubation for $2 \mathrm{~h}$, the medium was removed, and the 96-well plates were stored at $-80^{\circ} \mathrm{C}$ for at least $1 \mathrm{~h}$. Onehundred microliters of DMSO per well was added to dissolve the purple formazan product. The optical absorbance was measured at $590 \mathrm{~nm}$, with a reference wavelength of $630 \mathrm{~nm}$, by a microplate reader (Tecan 
Spectrafluor Plus, Tecan, Switzerland). The relative cell viability (\%) related to control wells treated only with $20 \mu \mathrm{L}$ of HBG was calculated as $([\mathrm{A}]$ test $/[\mathrm{A}]$ control $) \times 100$. All experiments were performed in triplicates.

C5A Complement Activation: $2 \mu \mathrm{L}$ of a polymer solution in PBS $(1 \mathrm{mg}$ $\mathrm{mL}^{-1}$ ) was incubated with $18 \mu \mathrm{L}$ of serum for $1 \mathrm{~h}$ at $37^{\circ} \mathrm{C}$. Polymerinduced activation of the complement system was assessed by applying the MicroVue C5a ElA kit by Quidel (San Diego, CA) according to the manufacturer's protocol.

Luciferase Assay: One day prior to transfection, Neuro2a/eGFPLuc cells were seeded at a density of 5.000 cells per well. After $24 \mathrm{~h}$ at $37{ }^{\circ} \mathrm{C}$, the medium was replaced with $80 \mu \mathrm{L}$ of fresh medium, $1 \mathrm{~h}$ before transfection. $20 \mu \mathrm{L}$ of the transfection-mix was added, which contains siRNA loaded star polymers ( $w / w$ ratios 1:3, 1:5, 1:10, 1:20 with $500 \mathrm{ng}$ siRNA per well) and HEPES buffered glucose (HBG) buffer. Used siRNAs were either siRNA against eGFP for silencing the eGFPLuc fusion protein, or the negative control siRNA without specific knockdown activity. After $48 \mathrm{~h}$ of transfection, medium was removed, cells were treated with $100 \mu \mathrm{L} 0,5 \mathrm{x}$ cell lysis buffer $(25 \mathrm{~mm}$ Tris, $\mathrm{pH} 7.8$, 2 mм EDTA, 2 mм DTT, 10\% glycerol, 1\% Triton X-100), and incubated for 30 min at RT. Luciferase activity in $35 \mu \mathrm{L}$ cell lysate was measured using a Centro LB 960 plate reader luminometer (Berthold Technologies, Bad Wildbad, Germany) and a luciferase-LAR buffer solution $(0.25 \mathrm{~mm}$ luciferin, $20 \mathrm{~mm}$ glycylglycine, $1 \mathrm{~mm} \mathrm{MgCl}$, $0.1 \mathrm{~mm}$ EDTA, $3.3 \mathrm{~mm}$ DTT, $0.45 \mathrm{~mm}$ ATP, $0.2 \mathrm{mg} \mathrm{mL}^{-1}$ Coenzyme A, pH 8-8.5). The relative light units were presented as percentage of the luciferase gene expression obtained with buffer treated control cells.

\section{Supporting Information}

Supporting Information is available from the Wiley Online Library or from the author.

\section{Conflict of Interest}

The authors declare no conflict of interest.

\section{Keywords}

polypeptide, polypept(o)ide, polysarcosine, siRNA, star polymers

Received: April 30, 2019

Revised: June 14, 2019

Published online: August 20, 2019

[1] A. Wittrup, J. Lieberman, Nat. Rev. Genet. 2015, 16, 543.

[2] M. L. Bobbin, J. J. Rossi, Annu. Rev. Pharmacol. Toxicol. 2016, 56, 103.

[3] C. Chakraborty, A. R. Sharma, S.-S. Lee, Mol. Ther. Nucleic Acids 2017, 8, 132

[4] R. R. Nikam, K. R. Gore, Nucleic Acid Ther. 2018, 28, 209.

[5] L. Aagaard, J. J. Rossi, Adv. Drug Delivery Rev. 2007, 59, 75.

[6] G. R. Devi, Cancer Gene Ther. 2006, 13, 819.

[7] H. J. Kim, A. Kim, K. Kataoka, Adv. Drug Delivery Rev. 2016, 104, 61

[8] J. Wang, Z. Lu, J. L.-S. Au, AAPS J. 2010, 12, 492.

[9] D. R. Corey, J. Clin. Invest. 2007, 117, 3615.

[10] M. Ogris, E. Wagner, Drug Discov. Today 2002, 7, 479.

[11] M. E. Davis, Curr. Opin. Biotechnol. 2002, 13, 128.

[12] S. Zhang, D. Zhi, L. Huang, J. Drug Targeting 2012, 20, 724.

[13] Y. Sakurai, H. Hatakeyama, H. Harashima, Mol. Ther. 2013, 21, 1195.

[14] E. Wagner, Acc. Chem. Res. 2012, 45, 1005.
[15] J. H. Jeong, L. Christensen, S. W. Kim, Biomaterials 2007, 28, 1912.

[16] M. E. Davis, Mol. Pharmaceutics 2009, 6, 659.

[17] M. Neu, D. Fischer, T. Kissel, J. Gene Med. 2005, 7, 992.

[18] U. Lächelt, E. Wagner, Chem. Rev. 2015, 115, 11043.

[19] A. Hall, U. Lächelt, S. M. Moghimi, Mol. Ther. 2017, 25, 1476.

[20] D. Oupicky, M. Ogris, L. W. Seymor, Mol. Ther. 2002, 5, 463.

[21] M. M. Schmidt, K. D. Wittrup, Mol. Cancer Ther. 2009, 8, 2861.

[22] S. Barua, S. Mitragotri, Nano Today 2014, 9, 223.

[23] R. K. Jain, Cancer Res. 1987, 47, 3039.

[24] H. Cabral, Y. Matsumoto, K. Kataoka, Nat. Nanotechnol. 2011, 6, 815.

[25] H. Maeda, H. Nakamura, J. Fang, Adv. Drug Delivery Rev. 2013, 65, 71.

[26] B. Theek, F. Gremse, T. Lammers, J. Controlled Release 2014, 182, 83.

[27] Y. Tsvetkova, N. Beztsinna, F. Kiessling, Nano Lett. 2017, 17, 4665.

[28] T. Merdan, K. Kunath, T. Kissel, Bioconjugate Chem. 2005, 16, 785.

[29] T. K. Georgiou, Polym. Int. 2014, 63, 1130.

[30] M. Byrne, D. Victory, S.-A. Cryan, Biomater. Sci. 2013, 1, 1223.

[31] A. Sizovs, X. Song, J. Wang, J. Am. Chem. Soc. 2014, 136, 234.

[32] M. Dearnley, N. Reynolds, T. M. Hinton, Biomacromolecules 2016, $17,3532$.

[33] R. Holm, B. Weber, M. Barz, Macromol. Biosci. 2017, 17, 1600514

[34] K. Klinker, M. Barz, Macromol. Rapid Commun. 2015, 36, 1943.

[35] P. Heller, A. Birke, M. Barz, Macromol. Biosci. 2014, 14, 1380.

[36] P. Heller, D. Hobernik, M. Barz, J. Controlled Release 2017, 258, 146.

[37] P. Heller, J. Zhou, M. Barz, Small 2017, 13, 1603694.

[38] A. Birke, J. Ling, M. Barz, Prog. Polym. Sci. 2018, 81, 163.

[39] P. M. Klein, K. Klinker, M. Barz, Polymers 2018, 10, 689.

[40] I. Negwer, A. Best, K. Koynov, Nat. Commun. 2018, 9, 5306.

[41] T. Aliferis, H. Iatrou, J. Mays, Macromol. Symp. 2006, 240, 12

[42] A. Birke, D. Huesmann, M. Barz, Biomacromolecules 2014, 15, 548.

[43] R. Holm, M. Douverne, M. Barz, Biomacromolecules 2019, 20, 375.

[44] D. Huesmann, A. Birke, M. Barz, Macromolecules 2014, 47, 928.

[45] K. Klinker, R. Holm, M. Barz, Polym. Chem. 2015, 6, 4612.

[46] P. Heller, B. Weber, M. Barz, Macromol. Rapid Commun. 2015, 36, 38.

[47] M. Ruponen, S. Rönkko, A. Urtti, J. Biol. Chem. 2001, 276, 33875.

[48] P. Midoux, C. Pichon, P.-A. Jaffrès, Br. J. Pharmacol. 2009, 157, 166.

[49] P. Midoux, M. Monsigny, Bioconjugate Chem. 1999, 10, 406.

[50] J. Shi, J. G. Schellinger, S. H. Pun, Biomacromolecules 2013, 14, 1961.

[51] Q. Leng, P. Scaria, A. J. Mixson, J. Gene Med. 2005, 7, 977.

[52] A. L. Hansen, L. E. Kay, Proc. Natl. Acad. Sci. U.S.A. 2014, 111, E1705.

[53] M. A. Young, A. Malavalli, R. M. Winslow, Transl. Res. 2007, 149, 333.

[54] R. P. Garay, R. El-Gewely, J. K. Armstrong, Expert Opin. Drug Deliv. 2012, 9, 1319.

[55] X. Wang, T. Ishida, H. Kiwada, J. Controlled Release 2007, 119, 236.

[56] T. Ishida, M. Ichihara, H. Kiwada, J. Controlled Release 2006, 112, 15.

[57] A. Spungin, S. Blumberg, Eur. J. Biochem. 1989, 183, 471.

[58] B. Weber, A. Birke, M. Barz, Macromolecules 2018, 51, 2653.

[59] N. Gangloff, J. Ulbricht, R. Luxenhofer, Chem. Rev. 2016, 116, 1753.

[60] J. Ulbricht, R. Jordan, R. Luxenhofer, Biomaterials 2014, 35, 4848.

[61] C. Dohmen, D. Edinger, E. Wagner, ACS Nano 2012, 6, 5198.

[62] A. C. Hunter, Adv. Drug Delivery Rev. 2006, 58, 1523.

[63] T. Fröhlich, D. Edinger, E. Wagner, J. Controlled Release 2012, 160, 532.

[64] C. Troiber, D. Edinger, E. Wagner, Biomaterials 2013, 34, 1624.

[65] N. Trouche, S. Wieckowksi, G. Guichard, J. Am. Chem. Soc. 2007, 129,13480

[66] C. Ghosh, G. B. Manjunath, P. Akkapeddi, V. Yarlagadda, J. Hoque, D. S. S. M. Uppu, M. M. Konai, J. Haldar, J. Med. Chem. 2014, 57, 1428

[67] C. Fetsch, R. Luxenhofer, Polymers 2013, 5, 112. 